\title{
TRADE RULES AND TRADE CONFERENCES: THE FTC AND BUSINESS ATTACK DECEPTIVE PRACTICES, UNFAIR COMPETITION, AND ANTITRUST VIOLATIONS
}

The Federal Trade Commission seeks to protect both competitors and consumers from commercial deception, unfair competition, and violations of the antitrust laws. ${ }^{1}$ As originally intended by Congress, the role of the Commission did not include the direct protection of consumers as such from commercial deception. ${ }^{2}$ Rather, the Commission was conceived as an agency to protect competitors and prevent the further growth of monopoly. ${ }^{3}$ Thus the enforcement procedures provided by the Federal Trade Commission Act ${ }^{4}$ and its companion legislation, the Clayton Antitrust Act, were designed to halt those predatory and collusive practices believed to be the methods employed in advancing monopolistic schemes. ${ }^{6}$ Today, however, the scope of the

1. FTC Ans. Rep. 2, 3 (1952); Zealous Men of FTC, Fortune, Feb. 1952, p. 106.

2. Șee Rublee, Original Plan and Early History of the Federal Trade Cammission, 11 ACAd. Pol. Scr. Proc. 117-18 (1926). For study of limited early operations of the Commission in the field of commercial frauds and misrepresentation, see Handler, False and Misleading Advertising, 39 Y ALE L.J. 22 (1929).

3. Political pressure culminating in the establishment of the Commission had been stimulated by congressional opposition to the "Rule of Reason" for Sherman Act interpretation announced by the Supreme Court in Standard Oil Co. v. United States, 221 U.S. 1 (1911). President Wilson and dominant elements in Congress wanted specific legislation, enforced by an administrative agency, to substitute for judicial discretion under the "Rule of Reason" doctrine. For an exhaustive account of developments leading up to the drafting and passage of legislation creating the Commission, see GAskiL, Tre Regulation of Competition, cc. I-IV (1936) (hereinafter cited as GaskilL); Thompson, Highlights in the Evolution of the Federal Trade Commission, 8 GEo. WAsu. L. REv. 257 (1940).

4. 38 STAT. 717 (1914), as amended, 15 U.S.C. $\$ \S 41-58$ (Supp. 1952).

5. 38 Stat. 730 (1914), as amended, 15 U.S.C. $\$ \$ 12-27$ (1946) (Supp. 1952). The Act bars several practices such as exclusive dealing, tie-in contracts, merger of competing corporations, and interlocking directorates, where such practices would substantially lessen competition and tend to create a monopoly in any line of commerce. For the 1936 Robinson-Patman Amendment, see note 60 infra.

6. The Clayton Act's generalities and many qualifying phrases made it fall far short of the original goal of its proponents: i.e., to forbid, item by item, all the "actual processes and methods of monopoly . . . and hurtful restraints of trade" which had been disclosed by experience, and to provide stiff criminal penalties for violations of the prohibitions. H.R. Doc. No. 625, 63d Cong., 1st Sess. (1914). Failure to achieve this goal was one of the principal factors leading to the creation of the FTC and the delegation to the Commission of considerable regulatory powers, under the general mandate to prevent "unfair methods of competition." It was hoped that a Commission might control the activities which Congress was apparently unable to list specifically. Gaskill 40 et seq. Proponents of this course of action thought that "unfair practices" were a principal cause of monopoly and thus believed that the Commission would function 
Commission's work has been vastly expanded. It includes, for example, control of the deceptive advertisements in the nation's 20,000 publications and other advertising media, ${ }^{\top}$ control of affirmative labeling of content for textile products, furs, and drugs, ${ }^{8}$ and enforcement of the far reaching antidiscrimination provisions of the Robinson-Patman Amendment to the Clayton Act. ${ }^{9}$ Yet the means of Commission regulation are still basically those provided for use against a far smaller number of monopolistic offenders, and its staff is smaller than it was thirty-five years ago. ${ }^{10}$ Recently, especially since 1946 , the Commission has attempted to streamline its antiquated enforcenent procedures and enhance its enforcement impact by developing methods of informal enforcement and industry-wide cooperation.

\section{FTC Enforcenent Procedures}

\section{Deceptive Practices and Unfair Competition}

Traditionally, the Commission has sought to exercise control over illegal competitive practices and product misrepresentation by issuing cease and

to control "trusts" in their incipiency. The specific practices discussed in congressional debate corresponded closely to the predatory practices of large corporations. Blarsuzer, The Federal Trane Cosmisston 19 (1932).

7. FTC ANN. REP. 50 (1952). And in the advertising ficld itself, the area to bo controlled expands constantly: $\$ 200$ million a year vas spent on advertising in 1969 ; in 1951 the figure rose to $\$ 6.5$ billion. Id. at 10 . And see notes $\mathrm{S}, 14 \mathrm{infra}$.

8. Specific authority to prevent the "false advertisement" of foods, drugs, medical devices, and cosmetics is contained in $\$ \$ 12-16$ of the Federal Trade Commission Act, added by amendment in 1938. 52 STAT. 114 (1938), 16 U.S.C. $\$ \$ 5-6$ (1946). Representation that oleomargarine "is a dairy product" is barred by $\$ 15(2)$, added by" the Oleomargarine Act, 64 STAT. 20 (1950), 15 U.S.C. $\$ 55$ (3)(2) (Sugp. 1952). The Commission administers the Wool Products Labeling Act, 54 SrAr. $1123(1940), 15$ U.S.C. $\$ 68$ (1946), which requires all products represented as containing wol to disclose by tag, label, or other mark: (1) the lind and percentage of each different fitar contained in the product, including the respective percentage of "wool," "reprozesesd wool," and "reused wool"; (2) the maximum percentage of loading and adulterating material, if any; and (3) the identity of the manufacturer of the weol product or oi a person marketing the product in interstate commerce. See FTC A:s. RcP. $57-8$ (1953). Within the past year the Commission has begun to administer the Fur Products Labding Act, 65 Stat. 175 (1951), 15 U.S.C. $\$ \$ 69 \mathrm{c}$-j (Supp. 1952), requiring similar diselosures on fur products giving the true English name of the animal producing the fur (as set forth in a Fur Products Name Guide), telling when dyed or bleached fur is used, and stating whether a substantial part of the product is composed of used seraps, or waste fur remanents. The Administration of both Acts is condueted by the Cummission"s Division of Wool and Fur Labeling. FTC Aws. REP. 59-60 (1952). Additionally, the Commission has enforcement duties under the Lanham Trade Mark Act, 60 Srxs. 427 (1946), 15 U.S.C. $\$ 1051$ et seq. (1946) and various amendments to the original Federal Trade Commission and Clayton Acts.

9. 49 STAT. 1526 (1936), 15 U.S.C. $\$ 13$ (1946).

10. In 1918, the Commission employed 699 persons; in 1939, 687; but as of Nov. 3v, 1952 , only 657. FTC ANN. REP. 10 (1952). In roughly the same period, along with thy Commission's increased duties, the number of business firms operating in the Enited States has doubled, and the gross annual product increased threefold. Ibid. 
desist orders directed against specific practices of individual offenders.11 Responsibility for administering such control procedures rests with the FTC's Bureau of Antideceptive Practices. ${ }^{12}$ When complaints ${ }^{13}$ or investigations by the Bureau staff ${ }^{14}$ indicate the use of deceptive practices which a firm under the Commission's jurisdiction ${ }^{15}$ will not voluntarily abandon, a formal complaint may be issued against the offender. Evidence of violations discovered by the Bureau and respondent's defense are then presented in formal hearings conducted by an independent trial examiner. ${ }^{16}$ This trial examiner makes an initial decision which includes: (1) findings and conclusions, with supporting reasons, upon all material issues of fact, law, or discretion presented in the record; and (2) an appropriate cease and desist order enjoining further use of any specific practices found to be illegal.17 These orders become FTC decisions ${ }^{18}$ unless appeals are taken to the Commission or unless the Commission on its own initiative dockets a case for review..$^{10}$

Under the Federal Trade Commission Act, once a cease and desist order becomes final, ${ }^{20}$ further violations detected by the Commission may result in imposition of heavy fines. ${ }^{21}$ However, a firm which wishes to continue use

11. See, e.g., Federal Trade Commission v. Gratz, 253 U.S. 421 (1920); Mennen Co. v. Federal Trade Commission, 288 Fed. 774 (2d Cir. 1923). For discussion see Frecr, Federal Trade Commission Procedure and Practice, 8 Geo. Wasr. L. Rev. 316, 330 (1940).

12. FTC ANN. REP. 40 (1952).

13. Complaints from outside sources alleging deceptive practices totaled 2,544 in fiscal 1952. Id. at 51 .

14. The Division of Investigation of the Bureau maintains a contintous sampling survey of major advertising media. The Division examined a total of 636,096 advertisements during fiscal year 1952. Its field representatives often detect misbranding and misrepresentation and other unfair and deceptive practices throughout the United States. Ibid. In administration of the Wool Products Labeling Act, the Bureau's Division of Wool and Fur Labeling inspected, by sampling method, 20,823,954 wool products during fiscal 1952. Id. at 57 .

15. The jurisdiction of the FTC with respect to interstate commerce has been strictly construed, and limited to matters directly relevant to interstate commerce. Federal Trade Commission v. Bunte Bros., 312 U.S. 349, 351-5 (1941).

16. FTC Rules of Practice, Rule 14, 16 CoDE FEd. Regs. $\$ 2.14$ (Supp. 1950) ; FTC ANn. Rep. 124 (1951). For status of these examiners, see id. at 8; DAvis, AdministusTIVE LAW 386 et seq. (1951).

17. FTC Rules of Practice, Rule 22, 16 Code Fed. REGs. § 2.22 (Supp. 1950); FTC ANN. REP. 127 (1951).

18. Ibid.

19. FTC trial examiners issued 109 initial decisions during the fiscal year 1952 : 54 were adopted by the Commission without appeal or review; 5 were reviewed by the Commission on its own motion; and 34 respondents appealed their initial decisions to the Commission. Of this group, 23 were pending at the close of this fiscal year, 8 were adopted, 2 modified, and 1 reversed. The remaining 16 initial decisions had been issted but not acted upon at the close at the fiscal year. FTC ANv. REp. 80 (1952).

20. See FTC Act, §§ 5(c), (g), 38 STAT. 719 (1914), as amended, 15 U.S.C. \$ 45 (Supp. 1952).

21. Punitive sanctions for violations of a cease and desist order are imposed for violations of the Federal Trade Commission Act, 52 Stat. 111 (1938), 15 U.S.C. \$ 
of a challenged practice can, by appeals, postpone the effective date of the order by as much as five years. ${ }^{22}$ About half of the initial trial examiner decisions are carried to the Commission for review, ${ }^{23}$ and further appeal may be taken to the circuit courts and the Supreme Court. ${ }^{24}$ Even under the most farorable conditions at least 6 months usually elapse before a cease and desist order becomes effective, following discovery of a violation. ${ }^{25}$ Fortunately, most offenders do not use the arsenal of delaying tactics to the limit. In faet, many firms prefer to drop challenged practices after a relatively informal settlement with the Commission rather than face the heavy legal costs and adverse publicity incident to formal FTC prosecutions. ${ }^{20}$ This willingness to settle, coupled with mounting backlogs of work and repeated criticisms of Commission dependence on statutory cease and desist orders as the primary method for correcting violations, ${ }^{27}$ have led to several recent procedural changes to facilitate informal settlement of individual deceptive practice cases. ${ }^{23}$

In cases of non-flagrant deception where it appears that the defendant acted in good faith and will not repeat the offense, the Bureau staff may now end the proceedings without publicity merely by closing the file on receipt of a letter or affidavit of discontinuance. ${ }^{20}$ However when a violation is considered

45 (1) (1946), but not the Clayton Act. See note 48 infra. Violations of cease and desist orders issued under the former act are punishable by a maximum fine of $\$ 5$, (i⿱⺈ separate violation of the order. In the case of a continuing violation, cach day of the violation is considered a separate offense. 60 StAr. 21 (1950), 15 U.S.C. $\$ 45(1)$ (Supp. 1952).

22. At the end of fiscal year 1952, proceedings to review five Commission orders against false advertising were pending in federal courts. FTC A:x. Rro. $\mathbf{5 6}, \mathbf{5 7}$ (1952). The FTC's initial formal complaints against advertising of thrce of these five companies had been issued seven or more years previously. $3 \mathrm{CCH}$ TRare Reg. REs., FTC Dock. Nos. 5342 (1945), 4970 (1943), 4960 (1943), 4772 (1942).

23. See note 19 supra.

24. During fiscal year 1952, 29 cases were decided in federal courts on netitions ior review of Commission cease and desist orders with the Commission's order taing reversed in only one. Fourteen cases were pending at the close of the fiscal year. FTC ANi:. REs. 54 (1952). During this same period 75 complaints and 108 orders to cease and desist were issued. Id. at 41 .

25. Geller, Advertising At the Crossroads: Federal Regulation: vs. Volunitary ControLs 174 (1952).

26. Id. at 168 . There have been assertions that the Commission has made oppressive use of the stipulation procedure in obtaining orders against innocent respondents who wish to avoid the expense and publicity of a formal proceeding. Apparently no independent investigation of these charges has been made. See D.Mns, AdMusistisutive LNW 152 (1951).

27. For criticism of FTC formal enforcement procedures, see, c.g., REP. ATT'Y Ger:. Conar. Ad. Proc 42 (1941); Hoover Comar. Rep. Task Force on Reg. Cossas. (1949).

2S. For FTC changes partially in response to the criticism, sce FTC Arts. Rer. 77 (1952); id. at $\$ 2$ (1951); id. at 5 (1950). For detailed discussion, see Propesals for Reform of FTC Procedures, 40 T.M. REP. 197 (1950).

29. During the fiscal year 1952, 269 cases, including 143 scheduled investigations and 126 preliminary inquires, were settled by such methods. FTC Azs. REr. 53 (1952). 
serious and there is need for greater assurance that the deception will not be repeated, a "stipulation agreement" may be offered a respondent. ${ }^{30}$ Sttch agreements consist of findings containing the jurisdictional facts and a statement of the acts and practices which the FTC had reason to believe were unlawful, together with an order to cease and desist. ${ }^{31}$ Both findings and order are entered by consent of the parties. ${ }^{32}$ Stipulations enable the Commission to obtain an effective cease and desist order without resort to time-consuming formal trials. ${ }^{33}$ They also benefit the respondent firm, because it may admit only jurisclictional allegations and not prior use of practices enjoined. Thus, such stipulations have no res judicata effect on the issue of past violations in any subsequent FTC proceedings against the offending firm. ${ }^{34}$ Similar consent settlements may also be made in formal proceedings prior to the taking of evidence on a complaint. ${ }^{35}$

But even if the FTC were considerably enlarged, these individual settlement methods would be unsatisfactory as a fair and effective means of coping with widespread unfair or deceptive practices within an industry..$^{30}$ This is particularly true where there is no general agreement for non-deceptive use of particular descriptive terms in marking or advertising a product, or where firms are forced to use illegal practices because of competitive pressure from

Apparently such settlements were not permitted before a Federal Trade Commission Order of June 29, 1949, cited in Geller, Advertising at the Crossronds 168 (1952). Almost all violations of the Wool Labeling Act halted by the Commission were corrected without formal prosecution. FTC ANv. REp. 57-9 (1952). Compliance was affected administratively in 14,696 cases of labeling deficiencies spotted by the Commission. Id. at 57 .

30. FTC ANN. REP. 74 (1952).

31. 16 FED. REG. 6503-4 (1951).

32. FTC Rules of Practice, Rule 5(1), 16 FEd. Reg. 6504 (1951).

33. FTC ANN. REP. 74 (1952). However, their violation does not bring comparable fines,

34. 16 FED. REG. 6503, 6504 (1951). Prior to this date, admissions of violations were required in stipulations. Sections 5(b) of the Administrative Procedure Act, 60 STAT. 239 (1946), 5 U.S.C. $\$ 1004$ (b) (1946), was designed to force the Commission to drop the requirement. Davis, Administrative Law 155 (1951).

35. FTC Rules of Practice, Rule 5(c), 16 FED. REG. 6503 (1951).

36. The Commission disposed of 182 cases under the stipulation procedure in the last fiscal year, FTC ANN. REP. 74 (1952), and issued cease and desist orders against 108 firms involved in unfair and deceptive acts and practices. Id. at 41 . Yet during the same period its own investigators or complaints from outside sources reported many thousands of violations, most of which were apparentiy not investigated. Id. at 51. Commissioner Mason has often denounced, as a type of discrimination, the Commission's use of selective prosecution, since parties not prosecuted-the large majority of offenders-are given great financial, social and competitive advantages over those selected for prosecution. Sce Address of Commissioner Mason before the Dayton Advertising Club, Nov, 6, 1947, copy in Yale Law Library; and speeches cited note 129 infra. Widespread use of a practice by a respondent's competitors, however, affords no defense to a cease and desist order. International Art Co. v. Federal Trade Commission, 109 F.2d 393, 397 (7th Cir.), ccrt. denied, 310 U.S. 632 (1940). Isolated prosecution of a few among many users of a condemned practice does not constitute prejudicial discrimination. National Candy Company v. Federal Trade Commission, 104 F.2d 999, 1004 (7th Cir.), cert. denicd, 308 U.S. 610 (1939). 
similar violations by other firms. ${ }^{37}$ In either situation, individual firms are most reluctant to accept a stipulation agreement which would require them to cease common practices if their competitors are not required to cease at the same time. ${ }^{3 s}$ Similarly, they are unwilling to make affirmative disclosures about their product if it would put them at a competitive disadvantage with competing products about which no similar disclosures were to be made.33 And if the Bureau of Antideceptive Practices should succeed in obtaining cease and desist orders against a representative offender, it would result only in putting that firm at a competitive disadrantage without effectively abating the general use of the injurious practices. ${ }^{40}$ To deal with such situations on an industry-wide basis, the FTC has developed its Trade Practice Conference Program, under its Bureau of Industry Cooperation.11

Under the Trade Conference Program the Commission conducts a series of informal and formal conferences culminating in formulation of a set of rules for industry behavior. The Commission seeks industry-wide agreement to drop unfair competitive practices common in the industry and urges adoption of appropriate standards for non-deceptive descriptions and labeling of industry products. ${ }^{22}$ The trade conference rules, in theory, do not create new law, ${ }^{43}$ but are issued to provide definitive guidance and information for businessmen as to what the Commission believes is required by the laws the Commission enforces. ${ }^{44}$ The FTC has no specific statutory authority for issuance

37. See GasknL 106 et seq. (1936); Thompson, Highlights in the Eralution of the Federal Trade Commission, S Geo. Wasm. L. Rev. 257, $268-9$ (1940).

38. GASKRL 106 (1936).

39. See note 37 sispra.

40. See note 36 supra, and public addresses of Commissioner Mason, citcd note 13it iinfra.

41. FTC Ann. Rep. 2 (1947). For representative discussions, sce Minuen, C:ifan Coampetition 281, 406 (1941); Cohen, FTC's Trade Practice Progranu loeflects Nica Industrial Attitude, Ind. Marketing, Jan. 19, 1947, p. 32; Nichols, FTC and Busisess Can Be Friends Under Trade Practice Plan, Printer's Ink, Sept. 27, 1946, p. 44. While the Commission is currently emphasizing the Conference Program, the first FTC-industry conference was held as early as 1918 to cope with deceptive marling by manufacturers of gold rings. The Commission had received a multitude of complaints that plated rings were being sold as solid gold or that the gold content of rings was misrcyrezented. But since these deceptive practices had not yet been forbidden by statute or decisional law, the FTC could only prosecute on grounds of unfair competition. Proof was dificult, how: ever, because such terms as "gold-shell," "gold-plated," and "gold-filled" had no accepted meaning within the industry itself. With the cooperation of leading ring manufacturers a conference was called and fair practices of marling gold content agresd upon. These standards, known as a "Trade Practice Submittal," were widely circulated and were used by the Commission as a basis for cease and desist orders. Soon after the ring confercnte, similar conferences were held in the creamery and in the book and writing-paper industries. GaskIL 108 et seq.

42. FTC ANN. Rep. 61 (1952).

43. 4 Callatann, Unfair Contretition and Trade Marms 2036 (2d ed. 1950) (hereinafter cited as CallimanN).

44. FTC ANN. REP. 63 (1952). 
of the rules, but relies instead on the early legislative history of the FTC Act 45 and on subsequent congressional appropriations made explicitly for the drafting and administration of the rules. ${ }^{46}$

\section{Antitrust Violations}

Formal complaint and enforcement procedures available to cope with the antitrust violations are similar to procedures used for deceptive practices and unfair competition cases. Since the Federal Trade Commission Act's ban upon unfair competition has been interpreted to encompass Sherman Act violations, ${ }^{47}$ formal procedures for attacking these violations are in fact identical with unfair competition and deceptive practice procedures. However, more cumbersome procedures are utilized to restrain Clayton and RobinsonPatman Act violations. Under Clayton and Robinson-Patman, the Commission cannot seek a fine when its order is violated, but must then obtain a court order prohibiting the practice. Punitive sanctions are brought into operation only when the subsequent court order is violated. ${ }^{48}$ The necessity of the stib. sequent order complicates enforcement headaches. FTC antitrust proceedings raise problems similar to those raised in deceptive practice and unfair competition proceedings: a small enforcement agency is faced with a huge enforcement task $;^{49}$ litigation is lengthy and may involve consiclerable delay ; ${ }^{50}$

45. See, e.g., Address of James A. Horton, Director, FTC Bureau of Industry Co* operation, before Chemical Soil Conditioner Industry, Nov. 10, 1952, copy in Yale Law Library (stressing the "Wilsonian concept" of giving industry advice and definite gutidance on legal matters). The legality of the rules is now unquestionable. See H.R. No. 3236, 81st Cong., 2d Sess. 31 (1951).

46. See, e.g., FTC Transcript, Hearings on Third Deficiency Approphiation Bill, FOR 1946 (June 7, 1946), copy in Yale Law Library.

47. Fashion Originators' Guild v. Federal Trade Commission, 312 U.S. 457, 463 (1941) ; Federal Trade Commission v. Beech-Nut Packing Co., 257 U.S. 441, 453 (1922).

48. 38 Stax. 734 (1914), as amended, 15 U.S.C. $\$ 21$ (1946). Originally, FTC orders under the FTC Act were enforced similarly, see 38 STAт. 720 (1914), but this was altered by the Wheeler-Lea Act, 52 Star. 112 (1938), as amended, 15 U.S.C. $\$ 45$ (1) (Stup. 1952). The Commission has twice recommended that the Clayton Act be amended in the same way because of the cumbersome enforcement procedure. FTC ANN. REp. 3 (1952); id. at 7 (1951). See Federal Trade Commission v. Ruberoid, 343 U.S. 470, 478-80 (1952).

49. In the FTC as well as the Justice Department, proceedings against major restraints of competition are deferred for lack of manpower. EDwands, MAINTAINing CoMpetition 298 (1951). The number of complaints received by the Bureau of Antimonopoly is not published. One estimate holds that the Bureau takes enforcement action against less than $1 \%$ of the Robinson-Patman violations reported to it. INTERviEws (an Editor of this JourNal interviewed a large number of FTC personnel, including Bureau Directors, Division and Unit chiefs, and staff lawyers in April and November, 1952, in connection with the preparation of this Comment; much of the information thus obtained was "not for attribution" or "off the record;" these sources will be cited as in this instance as INTERvIEvs). Even when a case is investigated, the Bureau apparently ncither closes nor dismisses the case, nor issues a formal complaint following $90 \%$ of the investigations. FTC ANN. REP. 27 (1952).

50. FTC ANN. REp. 8 (1951); see note 22 supra. 
and many defendants seem to be willing voluntarily to bring their practices into conformity with FTC interpetations. 51

In the antitrust field, however, the Commission has been reluctant to deviate from its formal complaint proceedings. Insofar as Sherman Act violations are concerned, the Commission apparently believes that clear collusive restraints of trade are entered into with lnowledge of their illegality and without any acceptable justification, and should thus be formally enjoined to prevent possible recurrence of the violation. ${ }^{52}$ Additionally, as a matter of policy, the Commission may refrain from settling such cases informally in order to prevent embarrassment of private or Justice Department litigation which might be brought on the same facts. ${ }^{53}$ There Clayton and Robinson-Patman violations are under investigation, informal settlements have been stymied also by the Commission's interpretations of its enforcement mandate. The latter Acts provide that the Commission "shall issue and serve a complaint" upon any person which it has reason to believe is violating the Acts. ${ }^{\text {os }}$ On the other hand, the Federal Trade Commission Act-passed concurrently with Clayton -provides that the Commission should issue complaints "if in the interest of the public." Fr From the discrepancy in wording the Commission has concluded, until recently at least, that formal prosecution is mandatory in all Clayton and Robinson-Patman cases. ${ }^{\text {to }}$ Thus, even when the respondent is willing to drop a practice before a complaint issues, the FTC continues litigation until the abandoned practice has been officially enjoined. ${ }^{67}$

Because of the Commission's attitude toward informal settlement of antitrust cases, the Trade Practice Program was not developed in response to

51. See concurring opinion of Commissioner Jason, Gruen Watch Company, FTC Dock. No. 5836 (March 17, 1952). This is true primarily of Robinson-Patman violations, not Sherman Act cases. In the latter, strong resistance by corporate defendants is common, and factual and policy problems complex. Enwarrs, Mrarisaninic Co:sretrTION 287 et seq. (1951).

52. Statement of Policy, FTC ANn. Rep. 138 (1951).

53. Ibid.

54. 3S Stat. 734 (1914), 15 U.S.C. $\$ 21$ (1946) (emphasis supplied).

55. 38 StAT. 719 (1914), 15 U.S.C. $\$ 45(6)$ (1946). Congressional suprorters of the FTC seemed to believe that fraudulent practices belonged in an altogether different category from the predatory practices of the "trusts," the prime evil sought to be curtailed. Thus Congress sought to guard against the Commission becoming so involved with control of common-law commercial frauds that its limited persennel would be diverted from the primary monopoly control task by inserting the provision that fraudulent practices should be prosecuted "if it shall appear to the Commission that a prosecding by it will be in the interest of the public." Rublee, Original Plan and Early History of the Federal Trade Conzmission, 11 Acas Pox. Scr. Proc 117-18 (1926).

56. FTC ANv. REP. 137, 139 (1951). But if. test at notes 157-66 infro.

57. Address of Commissioner Mlason before Section on Antitrust Law of the $\mathrm{New}$ York State Bar Association, February 19, 1953, copy in Yale Law Library. Sce, c.y., Deer v. Federal Trade Commission, 152 F.2d 65 (2d Cir. 1945); Edurators Ass'n v. Federal Trade Commission, 108 F.2d 470 (2d Cir. 1939), modificd, 118 F.2d 562 (2d Cir. 1941). See also Note, 53 HARv. L. KEv. 62S, 634-7 (1940). 
the need of providing more efficient techniques of administering antitrust laws. Rather, the origins of the program lie primarily in the deceptive practice field. ${ }^{58}$ And while most trade rules do contain provisions forbidding violations of the antitrust laws, these antitrust rules are usually verbatim restatements of the antitrust acts and are included merely for educational effect. ${ }^{60} \mathrm{Re}-$ cently, however, the Commission has taken steps which indicate that considerable use may be made of the Trade Practice Conference Program to curtail industry-wide violations of the Robinson-Patman Act. The Act prohibits any discrimination in price or services which may injure competition among sellers, buyers, or the customers of either ${ }^{60}$ Court interpretations of Robin* son-Patman's confused provisions made the status of the law unintelligible in many situations. ${ }^{61}$ The story of FTC action in the cosmetics industry aptly illustrates how factors similar to those present in the deceptive practice field are apparently influencing a shift to the trade conference procedure, at least in the Robinson-Patman portion of the antitrust domain.

The cosmetics industry had been in extended litigation with the Commission over manufacturers' payment of salaries of "demonstrators," i.c., clerks who demonstrate and sell the product in large department stores and specialty shops. ${ }^{62}$ The Bureau of Antimonopoly's lawyers had long contended that the Act's requirement that services furnished to buyers be "on proportionally equal terms" meant that cosmetics manufacturers must, contrary to their established practice, ${ }^{63}$ furnish the same service to all customers-including the corner drug store-or to none at all. ${ }^{64}$ In Elizabeth Arden, Inc. v. Fideral

58. See note 41 supra.

59. Communication to the Yale Law Journal from Allen C. Phelps, Chicf, Div. of Trade Practice Conf., FTC, dated May 29, 1952, in Yale Law Library. For typical anti * trust rules see note 111 infra. The inclusion of verbatim repetitions of the statutory language has been criticised as a "completely meaningless gesture." Weil, I.T.C.'s In* dustry Rules: How Do They Affect You?, Printer's Ink, Sept. 2, 1949, pp. 42, 48.

60. The Robinson-Patman Amendment of $\$ 2$ of the Clayton Act made it unlawful for at seller to discriminate in price between purchasers where the effect may be to lessen stibstantially competition $(\S 2(a))$; or to pay a customer for any services or facilitics furnished by the customer in connection with the sale, etc., of any products unless stich payment is available on proportionally equal terms to all other customers competing in the distribution of such products $(\S 2(\mathrm{~d}))$; or to discriminate in favor of one purchaser against another by furnishing services or facilities connected with the sale, etc., of the goods upon terms not accorded to all purchasers on proportionally equal terms (§ 2(e)). 49 STAT. 1526 (1936), 15 U.S.C. \$ $13(\mathrm{a})$, (d), and (e) (1946).

61. See Rowe, Price Discrimination, Competition, and Confusion: Another Lools at Robinson-Patman, 60 YALE L.J. 929, 972 (1951), and cases cited therein.

62. In the years 1936-1937 and again in 1940, the Commission issued seven com plaints against manufacturers of cosmetic products, alleging, in general, that these matutt= facturers had furnished the services of "demonstrators" to large department stores and had not furnished proportionate like services to other purchasers. 3 CCH TRADE REG. REP. 20,625 (1951)

63. See note 67 infra. See Statement by Commissioner Ayres in opposition to promulgation of the Cosmetics Industry Rules. 3 CCH Trane REG. Rep. 20,628 (1951).

64. Id. at 20,628-9. 
Trade Commission, ${ }^{65}$ and in a subsequent private action, Elizabcth Ardcn Sales Corporation v. Gus Blass Co., ${ }^{60}$ this position was seemingly upheld. A subsequent industry investigation by the FTC revealed that a sulstantial number of the industry's two hundred-odd manufacturers were engaged in similar practices. ${ }^{67}$ Presumably, competitive pressure from those persisting in "illegal" practices forced others to behave in like manner. Industry-wide case by case enforcement by the small staff was manifestly impossible; selective prosecution would have been unfair. Forced to attempt industry-wide action, the Commission on its own motion called a conference, ${ }^{63}$ probably under the urging of the few firms being formally prosecuted ${ }^{63}$ for practices indulged in by the entire industry. As a result of the conference negotiations, industry members and the Commission arrived at a specific code of behavior governing permissible use of "demonstrators." ro Currently, Commission action elsewhere also indicates that other Robinson-Patman trouble spots will be attacked via trade practice conferences. ${ }^{71}$

\section{The Trade Practice Conference Program}

\section{The Conference}

Requests for a conference may originate with either the FTC staff or industry and consumer groups. ${ }^{72}$ Typically, however, the impetus comes from industry members. ${ }^{73}$ Sometimes there is disagreement within the industry as to proper standards of marking and branding, sale methods, or terminology

65. 156 F.2d 132 (2d Cir. 1046), ccrt. denied, 331 U.S. 800 (1947).

66. 150 F.2d $98 S$ (Sth Cir. 1945).

67. INTERVIEWs. The investigation was apparently begun shortly after the Arden ease was affirmed in the court of appeals in 1946. See FTC Axw. REp. 3 (1947).

68. See FTC Ann. Rep. 3 (1947) ; 3 CCH Truie Reg. Rer. ff 20, 618 (1951).

69. Upon the successful completion of the Arden test case, the Conmission aprarently planned to press charges against other cosmetics firms on the six complaints issucd 9 years previously. Interitews. $3 \mathrm{CCH}$ TRANE Res. Kep. 20, 625 (1951). The actions against these firms were finally dropped more than five years after the first cosmutics trade practice conference was held. See note 166 infro.

70. For Cosmetics Industry Rules, see notes 116 infra. For general discusfiun of the rules, see Setting the Standards for Cosmetics and Toilet Goods Industry, Chenn. Wedt, Dec. 15, 1951, pp. 41-2. For an early proposed draft of these rules, see Opfeniness, UnfaIr Trade Practices 1218 (1950).

71. See note 122 infra.

72. Prior to 1946 , conferences were generally called only upon petition of the industry, FTC Axn. Rep 3 (1947) ; FTC Transcript, Helrmas on Thimb Deflie:icx AmmoPRIATION BILI for 1946, p. 8 (June 7, 1946), copy in Yale Law Library. Following a reorganization plan put into effect on August 12,1946, the Commission adonted a policy of initiating conferences on its own motion. FTC Rules of Practice, Rule $28(\mathrm{~b}), 16$ Cons FED. RECS. $\$ 2.28$ (b) (19-49), FTC ANN. Rep. 114 (1947).

73. Since 1946, the Commission has published rules for 36 additional industries. In only seven were the proceedings instituted on the Commission's own mstion. $3 \mathbf{C C H}$ TRADE REg. ReP. III 20,252-87 (1946-52). 
which cannot be resolved through an appropriate trade association. ${ }^{74}$ At other times conference requests apparently come from firms confronted with selective FTC individual prosecution for use of industry-wide practices, ${ }^{75}$ or from firms injured by a rival's false advertising or deceptive practices which they are unable to stop by private actions. ${ }^{70}$ But whatever the source, conference requests are studied by the Conference Division, and if the situation is of sufficient importance and personnel are available, it will recommend that the Commission grant the request. ${ }^{77}$

Planning a projected conference centers in the Rule-Making Unit of the Conference Division. Initially, Division attorneys check the files at both FTC enforcement arms, the Bureau of Antideceptive Practices and the Bureat of Antimonopoly, for information on every type of illegal practice in the industry that the Commission has noted. ${ }^{78}$ To curtail risks that the conference program might be used to further industry trends towards illegal collusion or combination, the Conference Division requests informal clearance for the confer-

74. INTERVIEWS. Lack of enforcement power has generally prevented effective trade association action to prevent deceptive practices. SHARP \& Fox, Business ETuics 251 (1937). See also 14 Encyc. Soc. Scr. 671, 674 (1933). Cooperative industry-FTC efforts in rule making often resulted in solutions of such problems. Communication to the Yale Law Journal from Paul M. Cameron, Ass't Chief, Div. of Trade Practice Conf., FTC, dated Feb. 25, 1953, in Yale Law Library.

75. INTERviews. The FTC seeks to guard, however, against use of conferences and informal settlements "as an easy escape for willful violators of the laws administered by the Commission." FTC ANN. REP. 138 (1951).

76. A right of action has long existed to restrain one businessman from "passing off" his goods as those of another by use of any technique through which the goods of one party to the suit will probably be accepted by the purchasing party as the goods of ankother. 1 Callasan 40, 71 et seq.; 3 id. at 1628 et seq. But these suits can be predicated only on the theory of passing off or on such other wrongful acts as are within the law of torts-e.g., trespass upon property, inducement to breach of contract, libel and slander, fraud, etc. See, e.g., Everett Piano Co. v. Maus, $200 \mathrm{Fed} .719$ (6th Cir. 1912); Katz v. Kapper, 7 Cal. App.2d 1, 44 P.2d 1060 (1935); Note, 9 So. CallF. L. Rev. 425 (1936). False or misleading advertising as such can not be enjoined. American Washboard Co. v. Saginaw Mfg. Co., 103 Fed. 281, (6th Cir. 1900). For the few exceptions to this general rule, see Callman, False Advertising as a Competitive Tort, 48 CoL. L. REv. 876, 878,880 (1948). Generally, absent special legislation or evidence of disparagement, or an attempt to drive a competitor out of business, it is impossible to succced in an action against one's competitors for false advertising. Id. at 878; 1 CALLMANN 300.

77. Personnel limitations require the Commission to defer a large portion of industry conference requests. "Dozens and dozens" of such requests were being deferred in 1946. FTC Transcript, Hearings on Third Defictency Appropriation Billo yor 1940, p. 15 (June 7, 1946), copy in Yale Law Library. The number of current applications is not made public, but apparently the backlog is larger than in 1946. Communication to the YALE LAw JouRnal from James A. Horton, Director, Bureau of Industry Cooperation, FTC, dated March 5, 1953, in Yale Law Library.

78. Communication to the Yale Law Journal from Alten C. Phelps, Chief, Div, of Trade Practice Conf., FTC, dated May 29, 1952, in Yale Law Library. 
ence from the Justice Department and all appropriate divisions of the FTC. If further field investigation is required, it is conducted by the Conference Division in conjunction with committees from the industry seeking the conference. ${ }^{80}$ And if distinctive rules are needed to clarify conditions for use of descriptive terminology, the FTC depends in large measure for advice and research assistance freely given by industry or Government agencies-primarily research assistance freely given by the industry or Government agenciesprimarily the Bureau of Standards. ${ }^{81}$

After assembling all available information, Conference Division lawyers prepare a tentative draft of industry rules, often with the substantial aid of an industry committee. ${ }^{82}$ These rules attempt to cover all illegal competitive practices uncovered in the preliminary investigation, and offer whatever affirmative standards are thought to be necessary as a guide to their correetion. ${ }^{83}$ In cases where the practice is common in many industries, the rule provision is lifted verbatim from the previous codes. ${ }^{82}$ Serious difficulties are often encountered, however, in the drafting of the "custom-made" rules, i.c., detailed provisions applicable to one industry alone. ${ }^{\mathbf{s t}}$

After a draft of suggested rules has been completed, all members of the affected industry are invited to a conference. ${ }^{80}$ Here the proposed drait is circulated, and representatives of the Commission explain their views as to

79. INTanvews. The FTC's Bureau of Antimonopoly apparently pasces up no oppertunity to object to conferences. In at least one case a conference was opguscd un a basis of a complaint received by the Bureau three decades before. InTEnvews.

80. INTERVIEWS.

81. Ibid. Bureau of Standards research assistance as an aid to Commission evaluztion of deceptive claims has recently been the subject of sharp political controversy. M.Y. Times, April 12, 1953, § E, p. 7.

82. Occasionally, the first tentative draft to be discussed at the cunierence may ba prepared by an industry committee alone. See, c.g., Proposed Trade Practice Rules ior the Smoking Pipe Industry (1952), copy in Yale Law Library, which served as the basis for discussions of the conference of that industry held in New Yorl: City, Octclisr, 1952.

83. Communication from Allen C. Phelps, note 78 supra; Communication from Paul M. Cameron, note 74 sispra.

84. While the phrasing of these standard provisions has baen varied and notifiul over a period of years, the substance of early rules is contained in the "boiler plate" pruvisions of recent rules. Compare, e.g., 3 CCH TRane REs. Rep. fl 20,189 (1935), rith id. II 20, 267 (1950) (all If provisions of Fire Extinguisher Appliance Mlanufacturing Industry Rules, promulgated Nov. 13, 1935, repeated without substantial change in Candy Industry Rules, promulgated Jan. 18, 1950). For example of expansion of criginally simple "boiler plate" provision into elaborate rules, compare early form of decsptivi guarasitee provision in Putty Manufacturing Industry Kules, Rule 12, id. 1720,223 (1939), sirit: detailed provisions in Piston Ring Industry Rules, Rule $8, i d$. 720,250 (1946).

S5. INTERVIEWS.

86. The Conference Division seeks to obtain from trade associations and other Government agencies all available lists of industry members in order to give individual notice to firms before conferences and public hearings commence. InTErviews. For the results of failure to give full notice to all members, although numbering several thousand, of an industry covered by rules, see discussion of Rules for Oil Heating Industry, New England States, note 172 infra. 
what conduct is required by law. ${ }^{87}$ The ensuing discussions from the floor often turn up aspects of the industry's competitive conditions either not considered or given insufficient weight in the initial investigations. ${ }^{88}$ Meritorious suggestions for changes or modifications in the tentative draft may be offered by participating businessmen. Following the conference, staff attorneys study these suggestions and prepare another draft. ${ }^{80}$ Usually only one industry conference is necessary, but in industries with complex problems or in which there is considerable opposition to the rules, as many as three conferences have been held in order to improve provisions and promote indtstry acceptance of the final rules..$^{90}$

When the proposed rules take final form, they are submitted to the Commission for preliminary approval. ${ }^{21}$ At this point the Commission holds a public hearing to which both industry members and representatives of consumer groups are invited.92 Following this hearing, provided no need is shown for substantial modifications, the Commission officially approves the rules $^{03}$ and copies are mailed to all industry members listed in FTC indexes and directories. ${ }^{94}$

87. Observations by an Editor of this Journal during Trade Practice Conferences, Smoking Pipe Industry, October, 1952.

88. INTERVIEWS.

89. INTERVIEUS; FTC ANN. REP. 68 (1951).

90. Communication to the Yale Law Journat from Lowell B. Mason, Commise sioner, FTC, dated October 29, 1952, in Yale Law Library. In preparing revised rules for the radio-television industry, the Commission held three formal conferences and many informal conferences. FTC ANN. REP. 68 (1952); id. at 75 (1951).

91. See note 93 infra.

92. Attendance at these hearings, as well as at conferences, is subject to marked variations, even where similar groups are involved. E.g., hearings on latest revision of Rayon and Acetate Textile Industry Rules, 3 CCH Trade REG. REp. đ 20,206 (1951), published December 11,1951, were well attended by industry members, along with representatives of the General Federation of Women's Clubs, the New York State Federation of Women's Clubs, Consumers Research, Consumers Union, Teachers of Home Economics, representatives of household magazines, and individual housewives. FTC ANN. REP. 65 (1952). In contrast, see FTC Holds Trade Practice Hearings on Ruls for Rayon, Nylon and Silk Converting Trade, Rayon, Nov. 1948, pp. 44, 46 (very stringent industry rules, but only small portion of trade present, and little discussion of pro posed rules). See 3 CCH TrAde REg. Rep. I 20,261 (1949).

93. The Commissioners review rules for an industry at two stages of the procecdings. After the conference is held the Commission reviews the proposed draft and suggests changes prior to the submission of a tentative draft at a public hearing. The draft is again reviewed by the Commission after the public hearing and in the light of all information submitted during the entire proceeding. At this second review the Commission approves the rules for final promulgation. See Communication to the YALE LAW JounNaL, from Allen C. Phelps, Chief, Div. of Trade Practice Conf., FTC, dated May 29, 1952, in Yale Law Library.

94. FTC Rules of Practice, Rule 33(g), 16 Code FEd. Regs. § 2.33(g) (1949); FTC ANN. REP. 131 (1951). Upon promulgation of the rules, they are tsullly printed in full in the trade journals of the industries affected, with little comment other than brief words of approval. See, e.g., Household Dye Trade Rules Issued, Oil Paint \& Drug Rep., 
The trade rules usually cover, at least in general terms, all practices likelv to be troublesome in the industry for many years following promulgation. However, certain "custom-made" rules, especially those dealing with advertising, may become quickly outdated. Advertising specialists are constantly devising new claims or promotional techniques, and research staffs create unforseen improvements in products. ${ }^{95}$ Competititve pressure in either event often leads to questionable advertising not covered by rules. As a result, the Trade Practice Conference Division is apparently trying to develop an informal auxiliary conference technique-without fanfare, public hearing, and full conference dressing-to keep its advertisement rules up-to-date.00 The first experiment along these lines is an effort to put appropriate boundaries around industry-wide lipstick advertising that claims a product is "indelible," "long-lasting" and "non-smear." If successful in curbing unwarrantel claims in this area, the Commission may use the same technique to govern claims about the effectiveness of chlorophyll content in other cosmetics industry products, ${ }^{98}$ and comparable trouble spots in other industries.

The final rules are officially divided into two categories. Rules in Group II merely codify practices which the industry recommends as a matter of business ethics or trade improvement, but which are not required by law. ${ }^{90}$ These rules, very general in terms, resemble a "Boy Scout" code and are of little significance except for slight educational effect. ${ }^{100}$ Group I rules, on the other

Feb. 3, 1947, p. 5; Credit Jewelers Adopt Fair Trade Practice Rules, Printer's Ink, June 28, 1946, p. 5; Here is Full Text of New Rules for Rayon and Acctale, Rayon, Jan. 1952, p. 44; FTC Trade Pracice Confercuce on Water-Resisiant Fabrics and Atparel, Rayon, Sept. 1948, p. 65; Trade Practice Rulles and Test Procedures for Textiles, 38 Axrer DYestufF REP. 274 (1949). For trade journal reports with severe criticism, see note 172 infra.

95. See Geller, Advertising at the Crossroads 67 et seg. (1952).

96. Food, Drug \& Cosmetics Reports P-2, August 16, 1952.

97. See 3 CCH Trade Reg. Rep. 12,413 (1953).

98. Ibid.

99. The Commission will not promulgate rules of this type unless the provisions are "in harmony with law and the public interest and are constructively in support of the maintenance of fair. competitive conditions in the industry." FTC Axw. Rer. 63 (1952).

100. Group II rules usually consist of provisions stating, c.g.: "Contracts . . . are business obligations which should be performed in letter and spirit." $3 \mathrm{CCH}$ Trade REG. REP. If 20,252, Rule B (1948). "The industry approves the practice of handling business disputes between members of the industry and their customers in a fair and reasonable manner ... [, and if no composition of differences results, of submitting] these disputes to arbitration." Id. If 20,256, Rule B (1947). Insofar as lawful, the industry and the FTC approve of distribution among members of the industry of credit information. Id. If 20,262, Rule D (1949). Others are more similar to some Group I rules. E.g., industry recommendation that peat products with high moisture absorbing qualities be sold on a dry measure basis, rather than by weight. Id. If 20,266, Rule A (1950). A few make recommendations to promote "open competition," such as independent publication and circulation, by each competitor, of his price lists and terms of sale among the purchasing trade. Id. I 20,267, Rule D (1950). A few industry rules contain Group II provisions recommending the compilation and distribution of industry statistics to the extent legally 
hand, are those provisions which the Commission feels express the requirements of federal law.101 This group contains both the "custom-made" and "boiler plate" industry rules. Group I rules may be divided into two general areas: those concerning deceptive practices and unfair competitive practices; and rules dealing with antitrust violations.

Modern rules dealing with deceptive practices and unfair competition range from highly generalized to highly particularized specifications for business behavior. A large portion of the trade rules now in force consist of standard provisions cataloging practices which have long been held illegal under the statutes enforced by the Commission. ${ }^{102}$ These "boiler plate" provisions, repeated verbatim in code after code, deal largely with such unfair methods of competition as commercial bribery, ${ }^{103}$ disparagement of competitors' products, ${ }^{104}$ circulation of false or misleading price lists and price tags, ${ }^{105}$ use of

permitted under antitrust decisions. Id. \| 20,267, Rule B (1950). Group II rules havo been the target of much criticism as innocuous expressions of platitudes and their complete elimination has been recommended. Oppenhers, Unfair Trade Practices 768 (1950). But considerable significance is attached to Group II rules as developing fair statudards which may eventually be required by law in Kittle \& Mostow, $A$ Review of the Tradc Practice Conferences of the Federal Trade Commission, 8 Geo. WAsH. L. REv. 427, 450-1 (1940).

101. Group I rules, according to the Commission, "embrace trade practices contsidered illegal under laws administered by the Commission and the Courts. . . . Adherence to [Rule] . . . requirements is mandatory upon all, quite irrespective of the fact that some industry members may have refused to take part in the establishment of rules or refused or failed to pledge obedience thereto." FTC ANN. REP. 63 (1952). For representative Group I rules, see notes 103-7, 109-13 infra.

102. The standard provisions summarize court decisions in language reasonably understandable to executives who operate the day to day affairs of business. Cohen, FTC Sponsors Industrial Competition, Self-Regulation, Indust. Marketing, March, 1946, p. 66 .

103. Forty-six of the 60 industry codes promulgated since 1940 contain commercial bribery "boiler plate" provisions. E.g., Bedding Manufacturing and Wholesale Distributing Industry, Rule II, 3 CCH TRADE REG. REP. If 20,276 (1950); "It is an unfair trade practice for a member of the industry, directly or indirectly, to give, or offer to give, or permit or cause to be given, money or anything of value to agents, cmployecs, or representatives of customers or prospective customers, without the knowledge of their employers or principals; to purchase or contract to purchase bedding products mantufactured or sold by such industry member or the maker of such gift or offer, or to influence such employers or principals to refrain from dealing or contracting to deal with competitors."

104. Forty-nine of the 60 industry codes promulgated since 1940 have containcd a provision similar to the following: "The defamation of competitors by falsely imputing to them dishonorable conduct, inability to perform contracts, questionable credit standing, or by other false representations, or the false disparagement of the grade, quality, quantity, substance, character, nature, origin, size, or preparation of any product of competitors, or of their business methods, selling prices, values, credit terms, policics, or services, is an unfair trade practice." Yeast Industry, Rule 10, 3 CCH TrAdE REd. REp. If 20,263 (1949).

105. "(a) The publishing or circulating ... of false or misleading price quotations, 
lottery schemes in retail distribution, ${ }^{100}$ and many other common forms of unfair or deceptive practices. ${ }^{\mathbf{1 0 7}}$ The meat of the rules, however, is contained in "custom-made" provisions patterned to control practices in a particular industry. ${ }^{10 s}$ Such provisions may be directed at advertising and sales methods, for example, by requiring that a product be of a particular type or meet certain requirements to justify use of a manufacturer's claims or use of certain designations. The detailed scope of conduct comprehended by the "custommade" provisions is aptly exemplified in the recent set of rules adopted for the pearl industry. The Pearl Industry Rules contain extensive provisions governing the use of such terms as "genuine," "natural," "Natura," "wild,"

price lists, terms or conditions of sale, or reports as to production or sales, with the capacity, tendency or effect of misleading or deceiving purchasers . . or affering jur sale of industry products ... at purported reductions in prices when such purpurtsl reductions are in fact fictitious or are otherwise misleading or deceptive, is an uniair trade practice.

"(b) It is an unfair trade practice... [in] offering for sale, industry jroducts at [purported reductions in price] ... or to furnish or supply for such use ... price tags, labels, or advertising material that set forth a false, fictitious, or exaggerated current, former, or regular price, or a false, fictitious, or exaggerated manufacturer's or distributor's suggested retail selling price.... It is likewise an unfair trade practice tu distrilusts.. products bearing such false, fictitious, or exaggerated price tags or labels." Pearl Indu-try, Rule 13, 3 CCH TRADE REG. REP. $\uparrow 20,255$ (1952).

106. Nineteen of the 60 codes promulgated since 1940 have containcd such provisors. See, e.g., Wholesale Confectionery Industry, Rule 6, 3 CCH Trirs REG. REr. $\Upsilon 20,252(1948)$.

107. See Office Míachine Marketing Industry, Rules, 3 CCH Trane Res. Rers. ${ }^{\circ} 20,253$ (1948), banning false invoicing, substitution of products, misreqresentation of produst as conforming to a particular standard, tie-in sales, deceptive guarantees, and misrepresentation as to installment sales contracts; Cocoa \& Chocolate Industry, Kuics, $i d$. If 20,275 (1950), banning misuse of the word "free," promoting moninuly by sulling below cost; Floor Machinery Industry, Rules, id. $\int 20.286$ (1952), banning dscertion in regard to new or rebuilt products and misrepresentation as to earnings of salcsmon; Wholesale Confectionary Industry, Rules, id. \20,252 (1948), banning use of bait advertising (small quantity of goods priced at unusually low price to draw custumers), and containing a very common provision requiring that a clear differentiation ba made bstween wholesale and retail transactions where carricd on at the same establishnucht. Common "deceptive practice" rules, exemplified by those in the Pearl Industry Rules, are bans on consignment distribution without the express request of the purchacer, false advertisement of "close-out" sales, "discontinued lines," or "special bargains," misrepresentation of functional nature of business (producer, manufacturer, importer). Id. II 20,285 (1952). Typical provisions banning traditional types of unfair competition are those found in the Floor Machine Industry Rules which ban unfair threats of infringement suits, inducing breach of contract, enticing away employees of comptitors, sccuring competitors' confidential information by unfair means, defamation of competitors and false disparagement of their products. Id. $\uparrow 20,286$ (1952).

108. A few rules are composed exclusively of "custom-made" rules. Sce, c.g., Tuna Industry, Rules, 3 CCH Trade Reg. Kep. T 20,229 (1945); Watch \& Wateh Case Industry, Rules, id. $\uparrow 20,253$ (1947) ; Mail Order Insurance Industry, Rules, id. $\therefore$ 20,263 (1950); Installment Sales and Financing of Mfotor Vehicles, Rules, id. I 20,273 (1951). See Note, Protection of Automobile Installinent Buyers: The FTC Stcps In, GI Yuxt L.J. 718 (1952). 
"cultured," "Kultured," "synthetic," "replica," and "reproduction" in the sale of pearls. ${ }^{108}$ Specific types of advertising, such as illustrations deceptively indicating the size of the pearls offered for sale, or deceptive use of pictures of oysters, deep sea divers, etc., in advertisements of imitation pearls are prohibited by the rules. ${ }^{110}$

109. 'It is an unfair trade practice to use the unqualified word 'pearl,' or any other word or phrase of like meaning or connotation, to describe, identify, or reicr to any object or product which is not in fact a pearl as defined in $\S 208.0$.

"It is an unfair trade practice to use the word 'pearl' to describe, identify, or refer to a cultured pearl uniess it is immediately preceded, with equal conspicuity, by the word 'cultured' or 'cultivated,' or by some other word or phrase of like meaning and connotation, so as to indicate definitely and clearly that the product is not a pearl.

"It is an unfair trade practice to use the word 'pearl' to describe, identify, or refer to an imitation pearl unless it is immediately preceded, with equal conspicuity, by the word 'imitation' or 'simulated' or by some other word or phrase of like meaning and connotiktion, so as to indicate definitely and clearly that the product is not a pearl. Note: The placing of an asterisk next to the word 'pearl,' which asterisk makes reference to a foot* note explanation of the fact that the product is an imitation or cultured pearl, is not regarded as compliance with the requirements of this section." Pearl Industry, Rule 2, 3 CCH Trade Reg. ReP. If 20,285 (1952).

"It is an unfair trade practice to use the word 'reproduction' or 'replica' as descriptive of cultured or imitation pearls.

"It is an unfair trade practice to use the term 'synthetic' as descriptive of an imitation or cultured pearl, or of any other product unless such other product has been artificially created and is of similar appearance and of essentially the same physical and chemical structure as a pearl. Note: Synthetic pearls possessing the same structure, properties, and characteristics as natural pearls have not yet been produced." $l d$. Rule 4.

"It is an unfair trade practice to use the word 'real,' 'gentuinc,' 'natural,' or 'wild,' or any other word, expression, or representation of similar import, in any way as descripa tive of any article or articles which are manufactured or produced synthetically or artificially, or which are artificially cultured or cultivated, or which are a simulation or imitation of or substitute for pearis, with the tendency and capacity or effect of misleading or deceiving purchasers, prospective purchasers, or the consuming public." Id. Rule 5.

"Examples of deceptive simulations within the inhibitions of paragraph (b) of the section are (1) 'Natura,' when used as descriptive of a culture or imitation pearl, and (2) 'Kultured,' when used as descriptive of an imitation pearl." Id. Rule $7 \mathrm{n}$.

110. "It is an unfair trade practice, in connection with the offering for salc, sale, or distribution of pearls, cultured pearls, or imitation pearls, to use, as part of any packaging material, label, advertisement, or other sales promotion literature, any picturc, illustration, map, diagram, or other depiction which, either alone or in conjunction with the words or phrases accompanying such depiction, has the capacity and tendency or effect of misleading or deceiving purchasers or prospective purchasers concerning the type, kind, grade, quality, quantity, size, character, substance, nature, origin, production, or preparation of any industry product, or which has the capacity and tendency or effect of misleading or deceiving the purchaser or consuming public in any other material respect.

"Note: For example, earrings set with five millimeter pearls should not be represented in advertisements by illustrations indicating that the pearl insets are a ten millimetcr sizc. Likewise, pictures of oysters, deep-sea divers, etc. should not be used in advertisements of imitation pearls in a manner which creates the impression that the products offered for sale are pearls or cultured pearls or products of oysters or of the sea." Id. Rule 11. 
In contrast, the antitrust rules have, until recently, never been more than a restatement of antitrust statutes. "Boiler plate" provisions summarize Sections 1 and 2 of the Sherman Act;"11 others prohibit tie-in clauses and exclusive dealing contracts offensive to Section 3 of the Clayton 1et; ;12 $^{12}$ and the whole gamut of Robinson-Patman prescripts is regularly included.113 In 1951, however, the FTC promulgated rules for the cosmetics industry which specifically interpret, not merely restate, Robinson-Patman provisions dealing with special services or payments. ${ }^{114}$ According to the industry rules, the Act's requirement that such services rendered by a supplier to a buyer, be "proportionally equal" does not demand that cosmetics manuiacturers must provide identical promotion services for all types of retail outlets: alternative services of proportionate cost will suffice instead. ${ }^{115}$ The rules explain in detail the scope of permissible differentiation in providing services. ${ }^{110}$ The current unofficial draft of rules for the athletic goods industry contains provisions

111. 26 Stat. 209 (1890), 15 U.S.C. $\$ \$ 1,2$ (1946). See, e.g., Slide Fastener Industry, Rule 14, which provides: "It is an unfair trade practice for a member of the industry:

(a) To use, directly or indirectly, any form of threat, intimidation, or coercisin against any member of the industry or any other ferson to unlawiully [sic] fix, maintain, or enhance prices, suppress competition, or restrain trade; or

(b) to enter into or take part in, directly or indirectly, any agreement, understanding, combination, conspiracy, or concerted action with one or more members of the industry, or with one or more other persons, to unlawfully [sie] fis, maintain, or enthance prices, suppress competition, or restrain trade." $3 \mathrm{CCH}$ TRune Res. Rep. ? 20,274 (1950).

112. 38 Sтaт. 731 (1914), 15 U.S.C. $\$ 14$ (1946). See, c.g., Venetian Blind Industry, Rule 23, 3 CCH Trade Reg. Kep. $\int 20,272$ (1950); Candy Industry, Rule 14, id. If 20,267 (1950).

113. The prohibitory clauses of the Robinson-Patman Act have been refeatel virtually verbatim in 53 of the 60 industry codes promulgated by the Commission since 1940 . 3 CCH TRADE REG. REP. If 20,234-86 (1941-52).

114. 49 STAT. 1527 (1936), 15 U.S.C. $\$$ 13(d), (e) (1946).

115. $3 \mathrm{CCH}$ Trade Reg. Rep. If 20,232, Rule 1(E) (1951). For a discussion, sce Shoenfeld, Now FTC Authorizes Altcriatize Sericios, Sales Mgm't, Jan. 1, 1952, p. \$0. The "proportionally equal" provisions of the Act had been criticised as ignuring considerations of efficiency, Edwards, Manntainisg Competitiox 168 (1951). They have bren called a "legislative monstrosity," Oppenheim, Should the Robinson-Patnon . Act Bc Amended? in CCH Robinson-Pataiax Srap. 141, 146 (1948). For general diccussions, see Rowe, Price Discrimination, Competition, and Confusion: Another Lool af RolinsonPatnan, 60 Yale L. J. 929, 959, 960 (1951) ; Layton, Demonstrators on Proportionally' Equal Terms in CCH Robinson-Patain ACt Sxirp. 51 (1948).

116. E.g., "Provided, however, that when the service, facility or allowance ufiered is of a type which under reasonable terms and conditions is not usable or suitable to the facilities and business of all customers and is offered to any one customer, the membar [may] offer each of those customers to whom the service, facility or allowance whtch is of equivalent measurable cost, is usable by the customer, and is suitable to his facilitics and business, and promptly inform all competing customers of the hind and amount of services, facilities or allowances which he has offered to each and the respactive terms and conditions under which ... [they] are to be furnishcd by the industry numbrr." 3 CCH Trade Reg. ReP. Iff 20,620-1 (1951). 
similar to the "proportionally equal" specifications in the Cosmetics Industry Rules and, additionally, offers further Robinson-Patman interpretation.117 The Robinson-Patman Act provides that a party may discriminate in price to "meet competition."118 An intricate Supreme Court decision, Standard Oil Co. v. Federal Trade Commission, ${ }^{110}$ may be interpreted as holding the "meeting competition" defense a hollow one, applicable only where a discriminator meets another's "lawful prices."120 The unofficial draft, however, sanctions a much-advocated broader interpretation of the "meeting competition" defense: the defense is valid insofar as the discriminator is "free of knowledge of any fact which indicates that the competitor's price" is unlawful. ${ }^{121}$ While there are other indications that the Commission will promulgate further interpretation and application of the antitrust acts-at least the Robinson-Patman Act ${ }^{122}$ -

117. Trade Practice Conference Attorney's Draft for Use at Conference for the Athletic Goods Industry, Sept. 18, 1952, Rule 1 (A) (5), copy in Yale Law Library, provides: "That nothing herein contained shall prevent the meeting in good faith of an equally low price of a competitor. (Note: Subsection (5), above, is to be understood as permitting an industry member to meet, but not exceed, the price at which goods of like grade and quality are actually being sold by a competitor, though such price be lower than the industry member's price to competing buyers and though the discrimination is not justified by subsections (1), (2), (3), or (4), above, only when the industry member is free of knowledge of any fact which indicates that the competitor's price which he is meeting is discriminatory and unlawful. ..."

For support for a broad interpretation of Standard Oil, see Rowe, Price Discrimina* tion, Competition, and Confusion: Another Look at Robinson-Patman, 60 YALE L.J. 929, 970-1 (1951). See also proposed legislation, H.R. 4170, 83d Cong., 1st Sess. (1953).

118. 49 STAT. 1526 (1936), 15 U.S.C. \$ 13(b) (1946).

119. 340 U.S. 231 (1951), 36 Iowa L. REv. 351. For interpretation of the decision, see Rowe, supra note 117, at 965-72; Austern, Inconsistencies in the Latv in CCH ANT1TRUST LAW SYMr. 158, 166-8 (1951) ; Simon, Price Discrimination to Mect Competition, U. OF ILL. I. FoRUM 575, 584-92 (1950).

120. Standard Oil Co. v. Federal Trade Commission, 340 U.S. 231, 242, 244, 246, 247 n.14, 250 (1951). At page 244 , note 10 , the Court cites a lower court opinion as "indicating" that the price met must be lawful, but does not evidence any approval of that indication. At page 247, note 14, the Court refers to a similar "suggestion" in legislative history. The most conspicuous reference to "lawful" prices, however, appears in the heading of Section III of the opinion. Id. at 238. But neither litigant tendered an issue of lawful prices. Cf. Oral Argument, 18 U.S.L. WeEk 3209-11 (U.S. Jan. 17, 1950).

The decision was apparently interpreted to require that the price met be "lawful" in Balian Ice Cream Co. v. Arden Farms Co., 104 F. Supp. 796, 802 (S.D. Cal. 1952).

121. See note 117 supra.

122. See, e.g., the Majority Statement of the Commission accompanying the Cosmetics Industry Rules, which stated: "It is true that the rule presents complexities but so does the law itself, and the Commission being charged with the duty of administering the law has a corresponding duty to attempt a reasonable interpretation of it in a practical manner and not refrain therefrom by reason of any suggestion of difficulty or magnitude." 3 CCH TRAdE REG. REP. 20,627 (1951). The main reason other Robinson-Patman interpretations have not been made since the cosmetics conferences has been lack of personnel in the Rule-Making Unit of the FTC for such work. Interview, Commissioner Lowell B. Mason, April 2, 1952. And see notes 164-6 infra. 
currently existing rules, apart from sparse Rohinson-Patman interpretative rules, remain overwhelmingly a compilation of "boiler plate" condensations of the antitrust acts. ${ }^{123}$

\section{Aftermath of the Conference}

Deceptive Practices and Unfair Compotition. After a conference the Commission may drop plans to bring formal action against individual firms to enjoin previous use of practices covered by rules, if firms signify their intention to abide by the new rules by signing an "acceptance card."12s Formal complaints alleging practices covered by the new rules may be terminated by a motion to suspend, while investigations which have not reached the complaint stage may be halted administratively. ${ }^{\text {12s }}$ However, such actions are without prejudice to the Commission's right to reopen the matter. In some situations, the Commission may refuse to settle a complaint even though compliance is tendered. The Commission specifically restricts use of the trade conference method as a settlement and correction technique to those firms which demonstrate a "good faith [intent] to correct unlawful practices on a cooperative and voluntary basis." 120 Therefore, when there is evidence of deliberate intent to defraud or of false advertisement of inherently dangerous products, violations are not closed by a firm's "acceptance" of conference rules. ${ }^{127}$

Successful industry-wide settlement requires prompt enforcement against non-conforming firms. This entails continuing surveillance of competitive conditions following a conference. Until 1946 the Commission had no established machinery for maintaining contact with industries under trade practice

123. See note 113 supra.

124. Acceptance cards are furnished industry members upon promulgation of trade rules for their industry and are for their own use in aclsnowledging receipt of a copy of the rules and voluntarily expressing their intention to follow the provisions thereof in the conduct of their business. By signing an acceptance card one does nut, according to the Commission, divest himself of any legal rights or otherwise subject himedf to the imposition of any restrictions not imposed by existing law. Communication to the Yale Law Jounnal from James M. Mead, then-Chairman, FTC, datcd November 6 , 1951, in Yale Law Library.

125. FTC ANw. Rep. 114 (1948).

126. Ibid. A statement of policy as to settlement of cases by Trade Practice Conference procedures was adopted on Aug. 19, 1947, 12 FEo. REg. SS11 (1947) reprinted in FTC ANN. REP. 113 (1948)). For typical industry comment, sce FTC Sctling Up Trade Practice Conferences to Settle Complaints, Iron Age, Aug. 25, 1947, p. 110 (statement interpreted as not making wide departure from policies previously in force, but at least indicating that the Commission had placed itself in a position to talse a more liberal view of industry demands for settlement of disputes through trade practice conference procedures; it was thought to be the result of strong pressure for such action from higher official sources, probably the White House). Commissioner Mlacon states the Commission seldom permits cases to be settled by trade practice conferences. Interview, April 2, 1952.

127. FTC ANin. REP. 114 (1943). 
rules. ${ }^{128}$ In that year, however, the Rules Administration Unit of the Conference Division was established as a key part of the new emphasis on voluntary cooperative procedures to maintain law observance. ${ }^{120}$ Today, the Unit consists of a chief and about eleven assistants. ${ }^{130}$ This small staff bears the major responsibility for supervision of all rules promulgated since its establishment, ${ }^{131}$ and in addition attempts to bring industries with older rules into effective cooperation with the Commission. ${ }^{132}$

Complaints processed by the Rules Administration Unit come from it variety of sources. To some extent members of the Unit are able to check

128. Commissioner Mason stated on June 7, 1946, that of the 150 trade practice conference industries, "there has not been a one of those which has been supervised or had anybody to call on them." He noted further that although "there is a constantly changing complexion ... [of personnel] in the industr[ies], [yet] for 20 years we have not had one ... [man] go around and supervise or study or give any help to these 150 Industries which had trade practice conferences." FTC TrANscrIPT, HEARINGS, 'THINo Dt. FICTENCY APPRopriatton BlLL FOR 1946, p. 22 (Jume 7, 1946), copy in Yale Law Library. Appropriations for trade practice conference work were only $\$ 34,633$ in 1945 , FTC $A N N$. REP. 83 (1945), and $\$ 26,057$ in 1946, $i d$. at 74 (1946). Yet the very small staft permitted by such appropriations conducted a number of conferences and negotiations through which many highly technical rules were formulated. Id. at 65 (1945); id. at 52.4 (1946) ; 3 CCH TrADE REG. REP. II 20,405-39 (1945-6). It is therefore doubtful that any significant amount of time was spent in rule administration. The discussions of seemingly extensive administrative activities and informal enforcement contained in the Comnission reports (FTC ANN. REP. 65 (1945); id. at 54 (1946)) are therefore misleading as to the actual state of affairs in trade rule administration at that time. After the Rules Administration Unit was established, and appropriations for trade conference work had doubled over that of the preceeding two years, the Commission guardediy said that "rule administration activities were undertaken to the extent possible with the personnel available for this work." Id. at 88 (1947).

129. Id. at 2, 4, 71. Commissioner Mason was the chief advocate of the development of rule administration as a substitute for formal prosecution of a small portion of violators. Zealous Men of FTC, Fortune, Feb., 1952, pp. 107-8. For his views, see such representative public addresses as Regulation by Conference, Oct. 13, 1947; FTC and Busincss-Firituds or Foes?, Nov. 14, 1947; First, Give Business the Job, Not the Works, April 6, 1943; The Federal Trade Commission with a New Look, Nov. 14, 1949; copies in Yale Law Library. For business reaction, see Clark, FTC Tackles the Gyp-Artist; Calls Indistry-quide Collferences that Correct Abuses, Protect Consumers and Industry Itself, Advertising \& Selling, March 1947, p. 112; FTC on a New Tack, Business Week, Nov. 30, 1946, p. 55; FTC" Setting up Trade Practice Conferences to Settle Complaints, Oil Paint \& Drug Rep., Aug. 25, 1947, p. 5; Nichols, FTC and Business Can be Friends Under Trade Practice Conference Plan, Printer's Ink, Sept. 27, 1946, p. 44; Cohen, FTC's Tradc Practice Confercnce Program Reflects New Industrial Attitude, Indust. Marketing, Jan. 19, 1947, p. 41. Congress appropriated $\$ 34,633$ for trade practice conference activities in fiscal 1945 , out of a total FTC appropriation of $\$ 2,054,070$. FTC ANs. Rep. 83 (1945). By fiscal 1951, this sum had been increased to $\$ 236,600$ out of a total FTC appropriation of $\$ 3,771$, 968. Id. at 91 (1951).

130. INTERVIEWS.

131. FTC ANn. Rep. 4, 71 (1947); id. at 61, 64 (1952).

132. The FTC's "administration" of older rules consists almost exclusively of processing complaints received. Personnel limitations have not permitted the establishment of effective liaison with many older rules industries. INTERviEws. 
compliance by field trips in which they contact key firms and trade association executives. ${ }^{133}$ Some information is forwarded by consumers injured by a rule violation. But the bulk of complaints originate either from competiturs anxious to see the rules observed, or from the Bureau of Antideceptive Practices which does extensive checking to uncover deceptive practices, in advertising and labeling. ${ }^{131}$ In addition, industry committees have been establishe. following a number of recent conferences, which seek to enforce olservance of the Commission's rules. ${ }^{135}$ Normally, such conmittees make the first effort to obtain compliance. Rules Administration seeks to maintain close liaison with these committees, and stubborn cases are forwarded to the FTC for action. ${ }^{136}$

Enforcement by the Rules Administration Unit proceeds on a highly informal, flexible basis. Operating on the belief that a timely warning is uitcn more effective than a tardy prosecution, ${ }^{137}$ the Unit has placel its chief emphasis on contact by informal correspondence, office conferences, and fiell visits. ${ }^{138}$ While firms often maintain stoutly that their challenged conduct is not illegal, the Unit is usually able to persuade businessmen tu modify their practices in a way which is satisfactory to the FTC. behavior can be obtained by presenting far less evidence and factual data than would be required to justify the issuance of a cease and desist order or even a formal complaint. 140 Ease of enforcement, however, uiten depends on the type of rule involved. Businessmen comply more readily with a pecific "custom-made" rule developed especially for the industry than with the gen-

133. Ibid. See also note 131 supra.

134. Other than violations reported by other FTC Divisions, abiut eighity y'scestit of complaints come from industry sources (primarily competitors) and ab.ut ten porcent from trade associations and better busines bureaus. The Rules . Meminitrationt Unit undertakes practically no investigatory activities. InTERvews. The Burcau of intideceptive Practices. Division of Investigation, was the prime source for repurts of porsibls deceptive advertising. That division supplied a total of 14,106 questionable advertics: ments to FTC operating division in 1952, a large purtion being sent to the Rules Aiministration Unit. FTC AxN. ReP. 51 (1952).

135. While a great many such committees have officially bien established, ske, e.y.n. $3 \mathrm{CCH}$ TRADE REG. REP. IfT 20,102-287 (1952), only about 10 are active to any effectiv: extent at this time. INTERVIENS.

136. INTERVIEWS.

137. See speeches of Commissioner Mason, nute 12y supra, Masun, FTC"s Scarth fur a New Role, Standardization, January, 1951, pp. 5, \&.

138. FTC ANx. Rep. 70 (1952). Administration of rules now: alsu involves an wessional industry conference in which top FTC Bureau of Industry Cooperation ofineials answer questions of industry members about the meaning of varitus rule provisions. Ese, Oftical Wholesalers Nat. Ass' $N$, etc, Conference Refunt (1950), cupy in Yale La: Library (containing transcript of proceedings of Optical Wholesalers Confirence, Nut: 9,1950 , the first of such conferences, held for "iniormative discussion" of the rccently promulgated rules for the Wholesale Optical Goods Industry).

139. INTERUIEWS; FTC ANN. Rep. 70 (1952).

140. INTERVIEW' 
eralized "boiler plate" provisions. ${ }^{141}$ The latter are open to more disputes over interpretation, and Unit personnel often must attempt to show the application of the rule to the challenged practice by pointing to related FTC orders or decisions. ${ }^{142}$ This experience seems to have reinforced the Conference Division's recent drive to emphasize specially-tailored rather than "boiler plate" rules. ${ }^{143}$

Where administrative persuasion fails to achieve satisfactory results in any case handled by the Rules Administration Unit, the case is referred to the Commission for formal enforcement by the Bureau of Antideceptive Practices. ${ }^{144}$ The Bureau's formal complaint, however, will not charge violation of the rule as such. ${ }^{145}$ Instead, since the Commission has no direct statutory authority to issue trade practice rules, 140 the offending practice is attacked either as a "deceptive act or practice" or "unfair method of competition" under Section 5 of the Federal Trade Commission Act, or as a "false advertisement" under Section 12 of the Act. In fact, the rules normally are not even introduced in evidence, although the respondent may have attended the conference and signed an acćeptance card. ${ }^{\mathbf{1 4 7}}$

Why the Commission avoids mention of the trade rules in formal proceedings is not wholly clear. One possibility is that the FTC wishes to avoid possible court challenge of its Trade Conference Program. ${ }^{148}$ Additionally, Trial Examiners thus far have declined to take official notice in any complaint

141. INTERVIEWS.

142. Ibid.

143. See, e.g., 3 CCH. Trade REg. Rep. II $20,285,20,284,20,283$ (1952) ; id. $\| 20,281$ (1951).

144. FTC ANs. Rep. 71 (1952); id. at 76 (1951). If and when informal administrat tion of the Clayton Act is authorized, continued violations of that Act not amenable to informal settlements would be referred to the Bureau of Antimonopoly for formal prosecution.

145. Communication to the Yale Law Journal from William M. King, Chief, Div. of Litigation, Bureau of Antideceptive Practices, FTC, dated March 12, 1953, in Yale Law Library.

146. 4 Caliman 2034.

147. See Communication from William M. King, supra note 145 , stating that "rules are not introduced in evidence, regardless of whether or not such member of the industry had subscribed or agreed thereto." However, rules, on occasion, have in fact been introduced in FTC proceedings as evidence of industry-recognized standards. See, c..., Fresh Grown Preserve Corporation v. Federal Trade Commission, 37 F.T.C. 824, 827-8 (2d Cir. 1943) (a partial report of the case is found in 139 F.2d 200).

148. In a trade practice conference in 1928 for cottonseed oil produccrs, rulcs fixing the price the producers were to pay to cotton ginners for cottonseed were agreed upon by the industry and approved by the Commission. A private suit was brought, charging that the conference and price-fixing agreed upon constituted a conspiracy and unlawful combine in restraint of trade, under state antitrust laws. The court discounted conduct in conformity with FTC Trade Practice Rules as being a defense, holding nothing in the FTC Act authorized the Commission to approve and promulgate such rules. Dothan Oil Mill Co. v. Espy, 220 Ala. 605 (1930), 127 So. 178 (1930). 
proceedings of prior Commission decisions on similar or identical issues. 143 Non-use of trade rules as evidence is consistent with such a policy but apparently not necessary. Moreover, Trade Practice Conference Division experts may be relied upon to testify to the deceptiveness of practices banned in the trade rules as a part of the "substantial evidence" of illegality presented in each contested proceeding. ${ }^{150}$ Proof of a similar conclusion by a trade rule may be considered largely superfluous or irrelevant.

Despite the FTC's reluctance to develop legal backing for its rules, rule provisions offer an accurate prediction of Commission attitudes toward particular trade practices. ${ }^{151}$ Unless a respondent can convince the Commission that, in effect, the rule provision previously promulgated was an insppropriate interpretation of law, in which case the rule would be revised, ${ }^{102}$ use of a practice condemned in a Group I rule normally will be enjoined by a Commission cease and desist order as a violation of the statute it interpets. ${ }^{103}$ And courts rarely disturb Commission findings of deceptiveness; the findings are conclusive on appeal if supported by eridence. ${ }^{15 s}$ Thus Trade Practice Rules are enforced in fact, though they are not given de jure recognition.

149. Communication from William M1. King, supra note 145.

150. In contested "proceedings, "the findings of the Commission as to the facts, if supported by evidence, shall be conclusive" 38 ST.IT. 730 (1914), 15 U.S.C. $\$ 45(c)$ (1946). This has been interpreted to mean, c.g., that "the findings of the Commission [are] conclusive if supported by testimony," Federal Trade Commission v. Standard Eduretion Society, 302 U.S. 112, 117 (1937), recicrsing \&6 F.2d 692 (2d Cir. 1936); that "the outcome turns, ... upon whether there was 'substantial' evidence to supgort the Commission's finding." Segal v. Federal Trade Commission, 142 F.2d 255, 256 (2d Cir. 1944). Until August, 1951, the Commission held hearings for the reception of evidence supporting the allegations of a complaint even though the respondent failcd to answer and agyear for a hearing. FTC ANN. REP. 79 (1952). In uncontested cases, "default orders" are now issued without production of evidence. FTC Rules of Practice, Rule 5(b), 16 Fal. REG. 6503 (1951).

151. Kittelle \& Mostow, A Review of the Trade Practice Conferences of the Fedcral Trade Commission, S GEo. WASH. L. REv. 427, 449 (1940).

152. INTERVIEWS.

153. The Commission officially states that all Group I rules express requirements of laws administered by the Commission and adherence to them by all industry members is mandatory, despite non-participation. FTC Axx. Rep. 63 (1952). Any substantive violation of a rule still approved by the Commission would be grounds for a case and desist order according to Bureau of Industry Cooperation officials. ImTEnminss. But ef. Communication to the Yale Law Jouranal from William M. King, Chief, Div, of Litigation, Bureau of Antideceptive Practices, dated March 12, 1953, in Yale Law Library, stating: "These rules are designed to establish standards of practice and conduct and constitute, as it were, a code of ethics; but they do not have any force of law. ..." At least one observer believes that some Group I rules do not accurately express the requirements of the statutes they purport to interpret, and therefore a violation of stch Group I rules would not be illegal. Weil, FTC's Indistry Rules: How Do They Affect Yous, Printer's Ink, September 2, 1949, pp. 42, 68. Nevertheless, the Commission does obtain considerable de facto compliance with such interpretations of the law by writing them into the Rules. Ibid.

154. See note 150 supra. The Commission might encounter some difficulty in obtaining substantial evidence that failure to follow a custom-made affirmative disclosure pro- 
Antitrust Violations. As late as this date, Commission procedures following a conference and formulation of trade rules have not been officially modified to produce and encourage informal settlements in antitrust cases. Clearly, most trade rule antitrust provisions, since they are merely verbatim statements of the antitrust statutes, could not be expected to augur or require any alterition in Commission insistence on full prosecution of all antitrust offenders. And, in fact, antitrust enforcement activity proceeds with practically no regard for the Trade Conference Programs. ${ }^{155}$ But in the cosmetics and wholesale optical goods industries, where "custom-made" Robinson-Patman trade rules have been promulgated, ${ }^{156}$ informal procedures along the lines of those used for deceptive practices might be anticipated. The pattern of administration of these rules is unclear. The 1952 Anmual Report of the Commission asserts that the Rules Administration Unit is checking on compliance with the cosmetics industry's Robinson-Patman rules, and indicates that informal enforcement activity is taking place. ${ }^{157}$ But there has been no announcement of official change in the Commission's view that the Clayton Act does not permit informal settlement of violations of such rules $;^{158}$ officially, the Bureau of Antimonopoly still has exclusive jurisdiction over these situations, ${ }^{\mathbf{1 5 0}}$ There are indications, however, that some official change may be forthcoming, by which the Rules Unit will be authorized to correct Robinson-Patman violations informally.

Recently, the Commission held hearings on its legal atthority to engage in informal settlement in the Clayton-Robinson-Patman field. ${ }^{160}$ At least part of the Commission's attitude of insistence on full prosecution stems from the wording of the enforcement mandate of the Clayton Act. ${ }^{161}$ But whatever validity this interpretation of the Clayton Act previously possessed may now be irrelevant under Section 5(b) of the Administrative Procedure Act. ${ }^{102}$

vision would result in deception of purchasers unless such disclosure is clearly needed. See, e.g., Mary Muffet v. Federal Trade Commission, 194 F.2d 504 (2d Cir. 1952) (provision to distinguish rayon from silk). The FTC burden may be lightened where past deceptive claims of the particular respondent must be countered by conspicuous and accurate affirmative disclosures. See, e.g., Haskelite Mfg. Co. v. Federal Trade Commission, 127 F.2d 765 (7th Cir. 1942). Courts seem willing, however, to support an order of the Commission on affirmative disclosure requirements unless there is a clear abuse of discretion. See, e.g., Hillman Periodicals v. Federal Trade Commission, 174 F.2d 122 (2d Cir. 1949) (order for conspicuous notice of abridgement of novels upheld).

155. Statement of Policy, FTC, ANN. Rep. 138 (1951).

156. See notes 115,116 supra.

157. FTC ANN. REP 70-1 (1952).

158. For ban on informal settlements of Robinson-Patman Act violations, see Statement of Policy, FTC ANn. REP. 137 (1951). See also Answering Statcment to Commissioner Mason's 'Concurring' Statement in Gruen Watch Company, FTC Dock. No. 5836, March 17, 1952.

159. FTC ANN. REP. 13 (1951).

160. Food, Drug \& Cosmetics Reports W-4, November 8, 1952; id. W-1, August 2, 195:.

161. See note 54 supra.

162. 60 STAT. $239-40$ (1946), 5 U.S.C. $§ 1004$ (b) (1946). 
This section of the APA offers general authorization for informal settlements, and legislative history indicates that the provision was aimed particularly at the FTC. ${ }^{163}$ Several months ago, a Commissioner was selected to conduct formal hearings on the issue, with the Bureau of Industry Cooperation supporting a change to informal procedures, and the Bureau of Intimonopoly defending the status quo. ${ }^{164}$

The deletion from its latest annual report of a standard feature of prior reports-a "statement of policy" containing a ban on informal settlements 105 -also suggests a change may be forthcoming. A further indication is the more recent Commission announcement that it is dropping its old complaints against six cosmetics firms, ${ }^{106}$ for use of practices condemned in the Elizabeth Arden case. This unprecedented maneuver by the Commission is apparently in partial recognition of the fact that the firms' prior violations have apparently been abandoned in good faith adherence to the new Cosmetics Industry Rules. Consequently, latest developments in all areas of FTC operation seem to constitute the prelude to attempts to extend the Trade Conference Program replete with informal methods of settlement at least into the RobinsonPatman area of the antitrust field.

\section{Impact of Trade Practice Confcrcnce Progran}

The precise impact of the Trade Practice Conference Program on competitive behavior is difficult to appraise. Detailed studies of the extent of deceptive practices in an industry before and after a trade conference apparently have never been made. ${ }^{107}$ Statistics based on formal complaints in rules and nonrules industries are unreliable because the Commission's limited enforcement staff results in sporadic and arbitrary case coverage of complaints. ${ }^{169}$ Consequently, observations on the extent of industry compliance must be based on informed opinions of industry members and FTC officials, a special field study of rule compliance in one industry, and on inferences from limited data in the Commission's official reports.

Estimates of the Conference Program's impact differ videly. The last major summary of information was issued by the TNEC in 1941.100 Relying primarily on opinions expressed in large numbers of commendatory letters received by the FTC from industry members, the TNEC reported that the rule program had made a strong impact on competitive conditions. ${ }^{170}$ Bureau of

163. Davis, Adainistrative Law 155 (1951).

164. See note 160 supra.

165. FTC ANN. REP. 136 (1951); id. at 127 (1950); id. at $114(1949)$; id. at 113 (1948); id. at 119 (1947); id. at 101 (1946); id. at 93 (1945).

166. 21 U.S.L. WEeK 2364 (FTC Jan. 27, 1953).

167. Communication to the Yale Law Journal from Allen C. Phelps, Chicf, Div. of Trade Practice Conf., FTC, dated May 29, 1952, in Yale Law Library.

168. See notes 13, 19, 36 sipra.

169. Control of Uxfair Coxtpetittre Prictices throlgi Trane Prnctice Chaference Prockdure of the Federal Trade Cossutssion (TNEC Monograph 34, 1941).

170. Id. at $19,25$. 
Industry Cooperation officials today place similar emphasis on the continuing stream of congratulatory letters stimulated by recent conferences. ${ }^{171} \mathrm{~A}$ recent industry-sponsored survey, however, indicates businessmen may hold less laudatory views in private. ${ }^{172}$ For example, a majority of the responses from industries covered by rules existing at the time of the TNEC report indicate a belief that the rules had little significant effect on competitive practices. ${ }^{173}$ A similar dichotomy exists within the Commission itself : men in trade conference work believe the contemporary program is highly effective, while those in the enforcement divisions generally hold a contrary view. ${ }^{\mathbf{1 7 4}}$ The Com-

171. Communication to the Yale Law Journal from James A. Horton, Dircctor, Bureau of Industry Cooperation, FTC, dated March 5, 1953, in Yale Law Library.

172. Views were made known to the Editors through a poll of representatives of 90 of the industries covered by Rules. The poll was conducted in 1952 by an industry group considering trade rules in order to gather information on the desirability of requesting a conference program for their industry. A copy of a confidential summary of this poll has been loaned to the Yale LAW JourNal. However, to preserve the confidential nature of this material, particular industries or respondents will not be identified. This study will be hereinafter cited 1952 INDUSTRY STUDY of Rules.

Generally, views expressed in trade journals are unrevealing. New FTC rules are rcceived with some fanfare and little adverse comment. See note 94 supra. A striking exception to the somewhat docile attitude of business towards the rules was that shown by segments of the oil heating industry of the New England states toward the rules promulgated for that industry in July, 1949. On July 6, 1949, the National Pelrolcum Newes reported: "New England fuel oil men are fuming over FTC's speedy approval and adoption of an 'oil heating industry' trade practice code while the fuel oil men still were protesting at the mere prospect that such a code might be brought forth. . . FTC brought forth the new code just 10 days after a Washington hearing with only a few changes from the draft discussed there." National Petroleum News, July 6, 1949, p. 18. The code was requested by the Oil Heat Institute of New England and opposed by the Independent Oil Men's Ass'n of New England, ibid., and the National Oil Jobbers Council. Id., July 27,1949 , p. 14 . The FTC apparently did not give individual notice to the thousands of independent fuel oil men in the New England states, who although in intrastate commerce and beyond the jurisdiction of the Commission, were urged to comply with the promulgated rules. Id. at 13. Two trade associations asked that the rules be withdrawn and submitted to the industry. However, when the Commissioners offered representatives of the associations only 15 minutes in which to present their suggestions for resubmission, the industry spokesmen declined to appear. Id., Aug. 3, 1949, p. 20. The Commission's official position was that the rules could be modified at any time upon proper showing of need. Id., Aug. 10,1949, p. 23. Its rather sharp treatment of industry protests was probably due to loud industry charges of "creeping socialism," etc., dirceted toward the Commission's efforts to assume "advisory jurisdiction" over the intrastate operators through a set of largely "boiler plate" rule provisions. Id., July 27, p. 13; id., Aug. 10,1949 , pp. 23-4. It seems likely that the Commission has had little success however in securing voluntary cooperation from those making the loud protests against the rules and conference procedures employed.

173. 1952 INDUStRy StUdy OF RULEs.

174. INTERVIEWS. Interbureau rivalry may be a primary cause of this difference of opinion. The Small Business Committee of the House reported: "Internal strife and office politics pervade the [FTC]. ... [T] here are many small cliques and groups whose chief interest is in personal authority and advancement. . . . The strengthening of part 
missioners range in their viewpoint from strong support to considerable skepticism. ${ }^{175}$

An initial distinction should be made between conferences held before and after 1946, the year in which the Rules Adninistration Unit was established. Prior to that time, promulgation of a code of rules virtually marked the end of the FTC's cooperative efforts. ${ }^{170}$ Once issued, the rules apparently were ignored by the Commission, except in their annual reports. ${ }^{177}$ The program was largely educational; the rules gave a guide to the honest as to what conduct the Commission considered illegal. Moreover, in many industries, even the educational effect was minimal. During the $1920^{\circ}$ s, rules were formulated ostensibly under Commission auspices, but, in fact, with little FTC supervivion over rule content. ${ }^{178}$ Eventually the Justice Department complained that the Commission's conference program had become an instrument of Sherman Act conspiracy. ${ }^{179}$ Somewhat red-faced, ${ }^{150}$ the Commission hastily withdrew existing industry rules and during 1931 and 1932 issued revised versions without consultation with the industries involved, and over their protests. ${ }^{181}$ These amended rules were composed largely of broad "boiler plate" provisions, many of which were expressed in terms of legal conclusions ${ }^{182}$ rather than specific

of the Commission's program is inevitably viewed by those interested in utiter activities as nothing less than a raid on their activities." H.R. No. 3236, S1st Cong., 2d Sess. 16 (1951). Traditionally, the prosecuting functions have attracted many of the most able men in the Commission, and much resistance to the trade practice conierence and industry cooperation programs has come from those with Civil Service litigation classitications. (Confidential Sources.)

175. See Zealous Men of FTC, Fortune, Feb., 1952, p. 106.

176. See note 128 supra.

177. Ibid.

178. GASKLL 119.

179. In an address on May 1, 1930, John Lord O'Brian, Assistant to the Attorncy General, stated that price fixing had been attempted in some instances "by a misuce of so-called codes of ethics or trade rules." Miller, Uwrar Cosiretrtion 271 (10i1). See note 148 supra. Similar criticisms and warnings had been expressed by the Commission's own legal staff, by outside observers, and consumer groups. G.1skinx 120; Kittelle \& Mostow, A Review of Trade Practicic Confercutes of the Fedcral Trode Commission, 8 Gro. Wash. L. Rev. 427, 436 (1940).

180. GaskILL 120-3.

181. The U.S. Chamber of Commerce called a protest meeting in Wachington of all affected industries in May, 1930. A second meeting was held in Niagars Falls, N.Y., late in September, 1930, called the "Congress of Industries," attended by representatives of 110 industries. This meeting expressed itself strongly against the revisions of the rulus, and in some instances pursuaded the Commission to modify its revisions. Bl.uspad, TuE Fedecal Trade Coamission 96, 97 (1932); Gaskml 122.

182. Group I rules, such as those forbidding the making of false or deceptive statements, imitation of trade-marks, or the defamation of competitors were formalizcd and restricted to instances "having the tendency or capacity to mislead or dcecive purchasers or prospective purchasers." Selling below cost, consignment selling, and cómmercial bribery were prohibited only when used "with the intent and with the efficet of injuring a competitor and where the effect may be to substantially [sic] lessen compstition or tend to create a monopoly or to unreasonably [sie] restrain trade." "The nct 
descriptions of the practices disapproved or approved. ${ }^{183}$ Similar codes, phrased in generalities, were issued throughout the early 1930's except during the period of the NRA. ${ }^{184}$ But even where rules were specific, since the Commission did little to effectuate compliance, forbidden practices were readopted, and borderline practices continued unchallenged. As a result, a large portion of the 179 codes even currently "under administration" have little educational effect, either because they have been forgotten or are so general or so outdated that they do not reflect newly developed practices and cannot be enforced fairly against practices banned. ${ }^{185}$

Some rules devised through the earlier conferences, however, fulfilled the educational function admirably and seem to have had a substantial impact on industry conditions. ${ }^{180}$ In general, the successful codes were those with many specific rules, clearly indicating which particular industry practices were considered deceptive and illegal-especially valuable in industries where conditions had been chaotic and deception rife. ${ }^{187}$ These "custom-made" rules

effect of these revisions was to confine Group I rules to a standardized set of rules [covering practices] which were clearly illegal under existing law, adding nothing new in principle and little in detail. ..." MiLLER, UNFAIR COMPETITION 272 (1941). For detailed illustrations of changes, see Hearings before Subcommittee of the Schatc Committee of the Judiciary on S.2626, S.2627, S.2628, 72d Cong., 1st Sess. 298.305 (1932).

183. See, e.g., 3 CCH TrADE REg. Rep. I 20,131 (1931). Group II rules deleted from the revisions included prohibitions of guarantees against price changes, antidumping provisions, elaborate provisions for publication of prices, allowances, and price changes, and elaborate regulations of competitive bidding in those industries where sealed bids are used. Míluer, op. cit. supra note 182, at 272. For detailed illustrations, see Hearings, supra note 182.

184. Much of industry drive toward regulation of competitive practices which had been manifest in the trade practice conference program was implemented for a while through the ill-fated NRA program. GASKmL 129, 149. For comparison with NRA Code provisions, see Kaidanovsky, Trade Practice Conference Rules of the FTC (NRA Div, of Rev., Work Materials 54, 1936).

185. 1952 Industry Study of Rules. For delays in rule revisions, see note 191 infra.

186. Kittelle \& Mostow, A Review of the Trade Practice Conferelles of the Federal Trade Commission, 8 GEo. WasE. L. Rev. 427, 449, 450 (1940); Nelson, Trade Practice Conference Rules and the Consumer, 8 GEo. WAsH. L. REv. 452, 467 (1940).

187. Confidential letters received in survey of trade association executives conducted by Yale LAw Journal, Jan.-Feb., 1953 (hereinafter cited as 1953 Journal SuRvex). One of the first elaborate codes was that for the rayon industry promulgated in 1937, which represented a sharp break with immediate trade rule precedents. A novel feature of these rules was their affirmative disclosure requirements. E.g., Rayon Industry, Rule 2 (3) declared that it was an unfair trade practice to offer for sale rayon products "without disclosure of the fact that such material or product is rayon." $3 \mathrm{CCH}$ TRADE REG. REP. \ 20,206 (1937, rev. 1951). The campaign leading directly to the adoption of these rules was inaugurated by various consumer groups. [1937] J. OF Horse EcoN. 466, 698. Consumer group and retailer demands were reflected in the preparation of the rules. Since the Wheeler-Lea Act of 1938, 52 StAт. 111 (1938), 15 U.S.C. \& 45 (1946), adding a prohibition of "unfair or deceptive acts or practices" to $\S 5$ of the FTC Act, had not been adopted at the time of the promulgation of these rules, there 
were often backed by organized consumer or industry groups anxious to see that all competitors compiled with FTC requirements. ${ }^{188}$ This increased the likelihood that private pressure or formal FTC prosecution would be employed to curb rule violations. But where these pressures were lacking, any initial improvement resulting from the educational efforts of the Conference Division appears to have been dissipated as banned practices were gradually readopted. . .

Rules promulgated in the last decade appear to have had a more impressive effect. $^{190}$ Greater numbers of specific rules are included in present-day codes, and some, but insufficient, attempts are made to revise old rules and bring them up to date. ${ }^{191}$ As a result, some sets of rules do constitute reliable criteria for those in the industry who wish to transact business entirely within the confines of the law. ${ }^{192}$ And since most industry representatives at the original conferences are still engaged in active management, the educational impact of the rules is considerable. At the same time, available evidence indicates that the recent conferences have achieved a higher degree of initial compliance, and subsequent conformity with the rules seems better sustained. ${ }^{103}$ This may be

was a considerable body of opinion that the affirmative disclosure requirement of the textile industry rules went beyond the scope of the authority of the Commission. See Kittelle \& Campbell, Paurer of the Fedcral Trade Comsission to Rewuire Informatize Labeling of Textiles, 20 B.U.L. Rev. 23 (1940). The Commission's requirement ai affirmative labeling of rayon products was upheld in Mary Afuffet, Inc. v. Federal Trade Commission, 194 F.2d 504 (2d Cir. 1952).

188. See note 187 supra.

1S9. 1952 INDUSTRY STUdy OF RULEs.

190. Ibid.

191. At least 65 of the 180 rules currently in force are in dire need of revision. INTERVIEWS. Five of the eleven sets of rules promulgated in fiseal year 1952 vere revisions of existing rules, FTC ANx. REP. 64 (1952); two revisions were among the nine sets of rules promuigated during the preceding year. Id. at $71-4$ (1951). During fiscal year 1950, only one of the ten sets of rules promulgated was a revision. Id. at 62 (1950). Thus, at the current rate of revision, there are probably more rules bacoming obsolete each year than are being revised and brought up to date.

192. Weil, F.T.C's Industry Rulcs: How Do They Affect Iou?, Printer's Inl, Sept. 2, 1949, pp. 42, 47, 48.

193. 1952 Industay Study of Rules; 1953 Journal Sunvey. And sce, c.g., auto financing experience: following the promulgation of the trade practice rules dealing with installment sale and financing of motor vehicles, $3 \mathrm{CCH}$ TRADE REO. REP. I 20,273 (1951), 43,000 dealers and finance companies signed and returned to the Commission acceptance cards signifying their intention to comply with the rules. FTC A:3:. REs. 72 (1952). Apparently 75,000 firms were sent such cards. Note, Profcction of Atstomobile Installinent Bityers: The FTC Sicps In, 61 YALE L.J. 71S, 725 n.35 (1951). Acceptance cards were received from 2,018 business firms following the various industry conferences held in fiscal 1952, but the Commission did not reveal how many were mailed to industry members. FTC ANN. REP. 63 (1952). The Commission is currently receiving a large number of commendatory letters from members of industries covered by rules supporting the trade practice conference work in all its asprets. Communication to the Yale Law Jouknal from James A. Horton, Director, Bureau of Industry Cooperation, FTC, dated March 5, 1953, in Yale Law Library. 
attributed, in large part, to the "follow up" program of the Rules Administration Unit in using the rules as a basis for informal enforcement. Before 1945, unless a complaint of rule violation was addressed specifically to the Trade Practice Conference Division, it was sent to another FTC Division for formal action; and, if personnel could be spared, the violation was formally enjoined by a cease and desist order. ${ }^{194} \mathrm{~A}$ number of such violations were enjoined in the 150-200 orders issued by the Commission each year before the Unit was put into operation. ${ }^{105}$ But by informal means alone, the Rules Administration Unit now reportedly halts rule violations on an average of 1000 cases per year, a figure almost three times the number of formal orders issued annually by all FTC enforcement staffs combined. ${ }^{196}$ And apparently, informal methods of obtaining compliance are successful: less than than 3 percent of reported violations have to be forwarded to other Bureaus for formal enforcement. ${ }^{107}$ However, these indicia of the program's efficacy in obtaining compliance must be read with other facts. There is direct evidence that rule compliance, despite many "acceptance cards," is a myth in areas where direct door-to-door" selling is involved. ${ }^{198}$ And reports of "successful" termination of offenders' activities must be tempered by recognition that the referent of "success" is

194. InteRviews. See, e.g., Fresh Grown Preserve Corp. v. Federal Trade Commission, 139 F.2d 200 (2d Cir. 1943).

195. At the beginning of fiscal year ending June 30, 1945, the Commission had pending 448 complaints, and docketed 164 during the year. It issued 140 orders to ceaso and desist, settled 4 by stipulations, settled 7 by acceptance of trade practice rules; dismissed or closed 19, and had 444 still pending at the end of the year. FTC ANN. REr. 60, table 2 (1945).

196. By informal methods, the Rules Administration Unit made "satisfactory dispo" sition" of 949 cases in fiscal year 1952, FTC ANN. REP. 70 (1952), and 1,100 cases in fiscal year 1951. Id. at 76 (1951). In fiscal year 1951, the Bureau of Antimonopoly issucd 23 orders to cease and desist unlawful practices, and the Bureau of Antideceptive Practices issued 98. Id. at 35, 49. In fiscal 1952, these two Burcaus issued 26 and 108 orders respectively. Id. at 27,41 (1952).

197. 1,100 cases were settled informally in 1951 , only 31 were referred to other Bureaus. Id. at 76 (1951).

198. Extensive research on the compliance of industry salesmen with applicable rules of the subscription and mail-order book publishing industry, promulgated September 3, 1940, 3 CCH TRADE REG. REP. If 20,233 (1940), indicates that although after promulgation of the rules the officers of most member companies no longer participate actively in the banned deceptive practices, most salesmen of the companies continue them. In the most flagrant example uncovered, the "sales pitch" used by one group of approximately 20 salesmen, all working for one company, and under the supervision of one sales manager, contained practically every one of the deceptive practices banned in the industry's elaborate custom-made rules, as well as supplementary rules which the industry voluntarily adopted to "reinforce" the FTC rules. Sunscription Book pulLishers, Additional Standards (1951), copy in Yale Law Library. Salesmen are discharged for violations of the rules, but the companies usually have a loose organizational structure which minimizes "main office" contact with salesman. Superficially, at least, this "frees" the companies of any knowledge of the deceptive practices being used in sales and training programs. While industry officials have been active in the formulation 
defined by the tiny eleven-man Rules Administration Unit. Of course, eleven men cannot maintain constant surveillance of the 954,000 rules industry members; undoubtedly many continued illegal activities remain undiscovered. And, in the light of their huge task, the Unit might well accept as "compliance" activities that others, such as the Bureau of Antideceptive Practices might heartily condem. But in any event, there is at least one other indication that the program does have some effect: industry requests for conferences seem to be increasing, and many businessmen are offering the FTC complete cooperation in the program. ${ }^{199}$

\section{Antitrust Violations}

Until recently, the Trade Practice Conference Program has had little impact on obtaining compliance with antitrust laws. As has been mentioned, antitrust trade rules were cast in generalities so broad that they added nothing to the antitrust statutes. And while more recent sets of rules have interpreted the Robinson-Patman Act for concrete industry problems, it is still too early to assess the effect, if any, of compliance activities to date..$^{200}$ Only one fact seems clear: cosmetics and optical goods firms who wish to provide services or discounts to customers now have guide posts marking legitimate ways-at least insofar as the FTC is concerned-that will not result in prosecution under some of the more troublesome clauses of the Robinson-Patman Act.

\section{The Trade Rule in Litigation}

While the FTC does not itself use trade rules in litigation, other parties may. Of course, where trade rules merely restate statutory provisions or concern practices already held illegal in adversary proceedings before the Commission or the courts, the rules are of no value in litigation either to the FTC or anyone else; statutes or decisions provide the authority and precedent for suit. There are trade rules, however, which explore new ground and which may even conceivably contravene court holdings. ${ }^{201}$ Were the FTC

and publication of the two sets of trade rules, and urge compliance within the industry, these efforts are apparently rarely directed toward the salesmen or sales managers of their own companies. Besgal, Courplance with Trane Practice Rules in Suberimton: Boor INDUSTRY 43, 44, 50-53 (unpublished report in Yale Law Library, 1953).

199. Communication to the Yale Law Jounsal from James A. Horton, Director, Bureau of Industry Cooperation, FTC, dated March 5, 1953, in Yale Law Library.

200. In connection with the Cosmetic Industry Rules, the Toilet Goods Ass'n warned its members last year that irreparable harm might face the industry unless there was general cooperation with the FTC on the rules. The Association noted that although the FTC had thus far been lenient, a careful check on compliance and crackdown in the many violators could eventually be expected. Drug Trade News, March 31, 1952, p. 4. Real enforcement of the Cosmetic Rules has been gostponed pending the outcome of the intra-FTC fight over the "voluntary settlement" proposal. Food, Drug \& Casmetics Reports W 5 , Nov. \&, 1952.

201. See notes 116,117 supra. 
the only party plaintiff in all areas in which it operates, even these rules might be irrelevant in litigation except as a guide to its enforcement staff. The Commission never uses rules to prosecute and, presumably as a matter of good faith, would not bring an action against one whose conduct is in compliance with the rules. However, along with the Commission, the Justice Department and private parties may sue for violations of the antitrust acts ${ }^{202}$ and, it is possible that private litigants will also be able to sue in federal courts for deceptive practices and unfair competition. ${ }^{203}$ These actions will raise the issue of the status of the trade rule in litigation, for private parties plaintiff may wish to introduce the rule as evidence that a defendant's activities are illegal. Or private parties defendant may wish to set up compliance with the rule as defense to a charge of illegal conduct.

\section{Deceptive Practices and Unfair Competition: The Lanham Act}

Until recently, a businessman usually could not restrain another's false advertising or deceptive promotion of a competing product, although his own sales may have been seriously injured. Generally, only where the competitor was deceptively "passing off" his goods as the products of the complaining firm or group could the deceptive practice be enjoined or damages recovered. ${ }^{204}$ Exclusive jurisdiction to enforce the specific prohibitions of deceptive practices contained in the FTC Act has rested with the Commission. ${ }^{205}$ The Lanham Act of 1946, however, although aimed principally at trade-mark protection, may also give private parties powerful federal remedies to control all types of unfair or deceptive practices affecting interstate commerce.

Section 43(a) of the Lanham Act gives any person "who believes he is likely to be damaged" by a competitor's use of any "false description or representation" of goods a claim for damages or an injunction. ${ }^{200}$ Similar relief is provided by Section 44,207 as protection against acts condemned in the Paris ${ }^{208}$ and Inter-American ${ }^{209}$ conventions on trade-marks and unfair competition. In addition to general provisions in both treaties requiring signatory

202. Clayton Act, $\S \S 4,15,16,38$ STAT. 736-7 (1914), 15 U.S.C. $\S \S 15,25,26$ (1946).

203. See note 219 infra.

204.' See note 76 supra.

205. Samson Crane Co. v. Union Nat. Sales, Inc., 87 F. Supp. 218 (D. Mass. 1949), aff'd per curiam, 180 F.2d 896 (1st Cir. 1950). A strong argument that the Commission's jurisdiction is not exclusive, and that private actions may be brought to enforce the prohibitions of $\S 5$ of the Act, is made in Bunn, The National Law of Unfair Competition, 62 HARv. L. REv. 987 (1949). This article has been cited with apparent aprpoval in Dad's Root Beer Co. v. Doc's Beverages, 193 F.2d 77, 80 (2d Cir. 1951), and Radio Shack Corp. v. Radio Shack, Inc., 180 F.2d 200, 202 n.1 (7th Cir. 1950).

206. 60 StAT. 441 (1946), 15 U.S.C. \& 1125 (a) (1946).

207. $\S 44(\mathrm{~b}),(\mathrm{h}),(\mathrm{i}), 60$ STAT. 441 (1946), 15 U.S.C. $\S \S 1126$ (b), (h), (i) (1946).

208. International Convention for the Protection of Industrial Propetrty, 53 Stat. 1768 (1934).

209. Gentral Inter-American Convention for Trade M[ark and Commencial. Protection, 46 Stat. 2907. (1929). 
powers to protect nationals of other treaty powers from "any act contrary to honest practice"210 or "contrary to commercial good faith," American treaty specifically condemns the use of "false descriptions of goods by words, symbols, or other means tending to deceive the public . . . with respect to the nature, quality, or utility of the goods."212 Remedies provided in the Ianham Act ${ }^{213}$ to enforce these provisions are available to foreign nationals of signatory nations and American citizens alike.214

The precise effect of these sections of the Lanham Act on private actions is still uncertain. Following several court interpretations that emasculated Section 43(a) as broad authority for private suits, ${ }^{215}$ plaintiffs shifted to Section 44 as support for their actions. In Stauffer ${ }^{2}$. Exley ${ }^{210}$ - the only controlling Court of Appeals interpretation-the Ninth Circuit held that Section 44 does create a federal action for unfair competition.217 Since the section

210. Treaty, supra note 20S, Art. 10 bis (2), 53 Srar. 1780 (1934).

211. Treaty, stipra note 209, Art. 21, 46 STAr. 2930 (1929).

212. "The following are declared to be acts of unfair competition and unless otherwise effectively dealt with under the domestic laws of the Contracting States shall be repressed under the provisions of this Convention:

"(a) ...

"(b) The use of false descriptions of goods, by words, symbols, or other means tending to deceive the public in the country where the acts occur, with respect to the nature, quality, or utility of the goods. ..." Id. Art. 21, 46 Srur. 2932 (1929).

213. Federal district courts have power to grant injunctions and rcquire reforts of compliance in order to prevent violation of rights to be protected by the Act. 60 Sris. 439 (1946), 15 U.S.C. $\$ 1116$ (1946). Where a violation of these rights has teen established, a plaintiff may recover, in so far as would be equitable, (1) the defendant's profits, (2) the plaintiff's damages, (3) the costs of the action. 60 Sr.1r. $439-40$ (1945), 15 U.S.C. \$ 1117 (1946).

214. G0 StaT. $441-3$ (1946), 15 U.S.C. $\$ 1126$ (b), (h), (i) (1946). These combined provisions apply to actions between citizens of the United States and provide the same federal remedies available to a foreigner sueing an American citizen. Sce March, Unfair Competition Defined, 37 T.M. Rep. 731, 735-6 (1947).

215. See Samson Crane Co. v. Union Nat. Sales, Inc, 87 F. Supp. 218, 22 (D. Mass. 1949), aff'd per curian, 180 F.2d 896 (1st Cir. 1950) (section bans only such false descriptions or representations "as are of substantially the same economic nature as those which involve infringement ... of trade-marks"; it should not be used to cover practices already banned by the FTC Act). Sce Californiz Apparel Creators v. Wieder of Cal., Inc., 162 F.2d S93, 900-1 (2d Cir.), cert. devied, 332 U.S. $\$ 16$ (1947), criticized in Callman, False Advertising as a Compctitio Tort, 48 CoL L. KEv. 376,834 (1948). The scope of $\$ 43$ (a) may well be extensively litigated in uther circuits in actions for personal injuries sustained as a result of using products whose properties are deceptively or falsely described. Cf. Carpenter v. Rohm \& Haas Co., 109 F. Supp. 739 (D. Del. 1952).

216. 184 F.2d 962 (9th Cir. 1950).

217. "[A]ny citizen or resident may invoke in the United States District Court, for acts of unfair competition, whatever appropriate remedies would be available under the Act if infringement of a registered trade-mark were charged." Id. at 9ot. "Effective protection against unfair competition is clearly essential to give effect to the International Convention for the Protection of Industrial Property ... and the General Inter-Ameriean Convention for Trade-Mark and Commercial Protection. ..." Ibid. 
covers deceptive practices and false advertising as well, private parties may sue in federal courts also on these grounds.218 Subsequent district court opinions in other circuits have disagreed, ${ }^{210}$ and the Second Circuit has

218. "So far as the conventions declare specific acts and practices unlawful a more or less definite area has been established [for rights created in the Lanham Act], but so far as interpretation of designedly broad terms is concerned" the meaning to be given "unfair competition" is constantly changing. Pagliero v. Wallace China Co., 198 Fi.2d 339, 342 (9th Cir. 1952). For example of specific acts condemned in the Conventionts, see note 212 supra.

219. Ronson Art Metal Works, Inc. v. Gibson Lighter Mfg. Co., 108 F. Supp. 755 (S.D.N.Y. 1952) ; Hosid Products, Inc. v. Masback, Inc, 108 F. Supp. 753 (N.D.N.Y. 1952); Old Reading Brewery, Inc. v. Lebanon Valley Brewing Co., 102 F. Supp. 434 (M.D. Pa. 1952) ; Ross Products, Inc. v. Newman, 94 F. Supp. 566 (S.D.N.Y. 1950). The conclusion of the Stanffer case was rejected on two grounds: (1) a broad federal substantive law of unfair competition under the Lanham Act is inconsistent with $\$ 1338$ of the Judicial Code enacted two years later, 28 U.S.C. $\$ 1338$ (Supp. 1952); (2) an unwillingness to interpet the Lanham Act as making so "radical" a change in existint: law in the'absence of "clear and unmistakable language." Section 1338 provides that the "district courts shall have original jurisdiction of any civil action asserting a claim of unfair competition when joined with a substantial and related claim under the copyright, patent, or trade-mark laws" (emphasis added). And in general, it codifies the rule established by judicial decision in Hurn v. Oursler, 289 U.S. 238 (1933). The contents of $\S 1338$ were suggested by Professor J. W. Moore to overcome a restrictive Second Circuit interpretation of the Hurn decision. See Kleinman v. Betty Dain Creations, 189 F.2d 546, 550 (2d Cir. 1951). The final text of $\S 1338$ was completed and printed in the Final Draft of the proposed Judicial Code prior to the passage of the Lanham Act, 60 Stat. 427 (1946), 15 U.S.C. $\$ \$ 1072$ et seq. (1946). Moore's Commentary on 'ritt U.S. Judicial CODE 64, 65 (1949) and the draftsmen did not discuss the then-pendingr Lanham Act. See Communication to the Yale Law Journal from Professor I. W. Moore, Member, Advisory Committee on the Judicial Code, dated April 23, 1953, in Yale Law Library. Nor, in considering $\$ 1338$, did Congress note the possible conflict with the substantive provisions of the Lanham Act, nor the lack of need for $\S 1338$ following the passage of the Lanham Act. The section was passed as submitted by its draftsmen. The reconciliation of the "conflict" in Stauffer v. Ex:ley, 184 F.2d 962, 965 (9th Cir. 1950), by giving $\S 1338$ independent significance as to pendant claims arising from transactions not affecting interstate commerce, although somewhat strained, seems much preferable to the district court's opinion that the broad rights claimed under the Lanham Act would make $\S 1338$ a "nullity" and therefore the Lanham Act private suits should not be permitted. Ross Products, Inc. v. Newman, 94 F. Supp. 566, 567 (S.D.N.Y. 1950). The district court argument-also supported by some commentators, c.g., 64 HARv. L. REv. 1209 et seq. (1951) - completely ignores the legislative history of $\$ 133 \$$. Moreover, while legislative intent of $\S 44$ of the Lanham Act may be considered cloudd -Note, Trade-Marks, Unfair Competition, and the Courts: Some Unsettled Aspects, the Lanham Act, 66 HARv. L. REv. 1094, 1102 (1953)-viewing $\$ 1338$ as an implicd repeal of $\S 44$ (i) seems wholly unwarranted when its background is posed against the stated general intent of the Lanham Act: "The intent of this Act is to regulate commerce within the control of Congress, ... to protect persons engaged in such conmerce against unfair competition . . . and to provide rights and remedies stipulated by treaties and conventions respecting trade-marks, trade names and unfair competition entered into between the United States and foreign nations" 60 STAT. 444 (1946), 15 U.S.C. \& 1127 (1946). No judicial alarm should necessarily arise over combination of unfair competition substantive laws with trade-mark legisiation: the American concept of unfair 
avoided a ruling. ${ }^{220}$ But in any event, at least in the Ninth Circuit, private actions under the Lanham Act do exist, and this is in accord with the views of most writers. 221

Since the private proceeding under the Lanham Act is relatively new, the legal status of the trade rules in such proceedings has not yet been adjudicated. Doctrinally, the trade rule represents only the view of an enforcement agency and the consensus of an industry-a view which has neither the status of a court decision nor an FTC finding of fact in a particular adversary proceeding that a specific practice is deceptive. Consequently, violation of a rule can not itself be sufficient to constitute a per se violation of the Lanham Act; nor would compliance with a rule bind courts to assert that no violation of the Act has occurred. Nevertheless, in practice, the trade rule may generally have these effects, at least in situations where rules cover deceptive practices which have not been directly examined in prior court opinions or Commission orders.

When confronted with conflicting claims as to whether or not an advertisement or sales practice is deceptive or a false description, the trier's determination of the issue rests largely upon whether an ordinary, trusting purchaser, relying on the fair meaning of an advertisement or sales representations would be misled as to the nature or quality of the product. ${ }^{.22}$ Unless conflicting standards generally accepted by the public were introduced-a difficult type of proof 223 -the rule provision may be the only relevant indication, for example, of the meaning generally given certain descriptive terminology or the

competition originates from the cases which relate to the appropriation of trade marls and trade names. Bunn, The National Law of Unfair Competition, 62 HAns. L. REv. 9S7, 1001; Haines, Efforts to Difinc Lufair Conprtition, 29 YaLE L.J. 1 (1919); Jones, Historical Dezelopment of the Law of Business Competilion, 36 YALE L.J. 12, 2007, 351 (1926).

220. Chas. D. Briddell, Inc. v. Alglobe Trading Corp., 194 F.2d 416, 421 (2d Cir. 1952) ; Dad's Root Beer Co. v. Doe's Beverages, 193 F.2d 77, 81 (2d Cir. 1051); Cutting Room Appliances Corp. v. Empire Cutting Mach. Co., 185 F.2d 997,999 (2d Cir. 1951); Ronson Art 11 etal Works, Inc. v. Comet Import Corp., 103 F. Supp. 531, 532 (S.D.X.Y. 1952).

221. See, c.g., Callman, False Adzertising as a Compctitize Tort, 45 COL. L. Kar. 876, \&86-7 (1948); Diggins, Federal and State Regulation of Trade-Marls, 14 Law is Contenr. Pros. 200 (1949) ; Ladas, Trade-Marlss and Foreign Trade, 39 T.M. Rre. 278, 288 (1948) ; Lunsford, Unfair Competition: Stope of the Lanham Act, 13 U. of PrtT. L. Ker, 533, 540, 542 (1952).

222. See note 227 infra. The trade practice conference procedure was originally conceived by the Commission as a means of obtaining from industry expressions of trade opinion ("submittals"), from which the Comnission might, in its discretion, formulate standards for proper use of terms dealing with quality and content of industry products. The violation of the standards would constitute the uniair mcthols of competition the FTC had power to prevent. FTC Trune Practice Susumtals 7 (16i25), discussed in Gaskill 110.

223. Fresh Grown Preserve Corp. v. Federal Trade Commission, 125 F.24 017 (2d Cir. 1942), modified, 37 F. T. C. $824827-8$ (2d Cir. 1943). 
affirmative disclosures which the purchaser relies upon in interpreting advertisements or examining goods. In these situations getting the rule before the court should not be difficult. Since a large percentage of the members of an industry usually formally acknowledge their acceptance of the rules as an industry code of competitive practices, ${ }^{224}$ the rules may well be admitted as evidence of prevailing custom and usage. Or a rule may be admissible as an admission against interest of a party who has assented to it. ${ }^{225}$ Conceivably, courts might even spell out a doctrine of estoppel : a plaintiff who, with other industry members, has assented to the rules may be estopped from asserting that practices in compliance with the rule are illegal; and conversely, a defendant may be estopped from challenging a rule to which he has assented as a valid stanclard of deception. In any event, the rule will be influential : it may constitute the only easily obtainable evidence, and it carries the weight of Commission expertise and common assent of industry members in an area where confusion might otherwise predominate. Should the courts pay the same deference to the rules as they currently do to Commission findings of deception in FTC proceedings, ${ }^{226}$ rules may generally be enforcible de facto, regardless of their official legal status.

\section{Antitrust Violations}

Both the Justice Department and private litigants, as well as the FTC, are authorized to bring actions against violators of the antitrust laws. The isste of the status of the trade rule in such proceedings has not arisen, hoivever,

224. Kittelle \& Mostow, A Review of the Trade Practice Conferences of the Fedcral Trade Commission, 8 Geo. Wash. L. Rev. 427, 449 (1940). And see notes 193, 124 stipra.

225. There appears to be no case support for this proposition. But at least one commentator has expressed this view: "The fact that such conduct is denounced by a rule is not even properly admissible in evidence against a respondent unless it can be shown that he in some manner or another acquiesced in the propriety of such rute or agreed to abide by it (as by signing an 'acceptance' form)." Weil, FTC's Indusiry Rulles: How Do They Affect You?, Printer's Ink, Sept. 2, 1949, pp. 42, 47. Since the Commission apparently seeks to avoid use of acceptance cards in its formal litigation, see note 147 supra, they are apparently used as a psychological aid in obtaining voluntary compliance and quick settlement of violations informally by rules administration. Since use of acceptances as admissions in private litigation might decrease drastically those firms signing the cards, the FTC would probably oppose the release of information as to who has and who has not signed such cards after a conference.

226. See note 24 supra. When considering FTC findings that a particular practice is deceptive courts have stated : "[T] he findings of the Commission [are] conclusive as to the facts if supported by testimony. The Courts cannot pick and choose bits of evidence to make findings of fact contrary to the findings of the Commission." Federal Trade Commission v. Standard Education Soc. 302 U.S. 112, 117 (1937). See also Mary Muffet, Inc. v. Fcderal Trade Commission, 194 F.2d 505 (2d Cir. 1952); Hillman Periodicals, Inc. v. Federal Trade Commission, 174 F.2d 122 (2d Cir. 1949); Segal v. Federal Trade Commission, 142 F.2d 255 (2d Cir. 1944) ; Fresh Grown Preserve Corp. v. Federal Trade Commission, 139 F.2d 200 (2d Cir. 1943). In the same way, the trade rules might represent a finding of fact by the Commission that all practices within a category are deceptive. 
since the recent Robinson-Patman rules mark the FTC's first important venture beyond restatement of antitrust statutory provisions.

The trade rule is likely to be of considerably less weight in antitrust proceedings than in the deceptive practice field. Whereas the deceptive practice cause of action rests largely upon custom and usage and judgments as to public reaction, ${ }^{227}$ these factors are generally irrelevant to the antitrust cause of action. At the same time, it is unliliely the courts will evolve estoppel doctrines built around the rules: estoppel is virtually dead in the antitrust field.2s Nor would compliance with a rule be a sound defense: good motives rarely insulate an antitrust violator from succesful attack. ${ }^{229}$ Since evidentiary relevance of the rule is thus difficult to establish, entry of the rule under an admission against interest theory serves no purpose. As a result, the trade rule can only be effective by virtue of the stature accorded an FTC interpretation of law, possibly through a device such as judicial notice, or through completely "non-legal" channels that might influence a court. This effect may be negligible as well, for pre-litigation interpretations of antitrust laws are given little credance: The Justice Department, for example, cautions all parties that they abide by Department interpretations at their own risk.230 And, contrary to traditional attitudes in the deceptive practice field, there is little reason to expect court deference to FTC rulings. Courts have always been the supreme arbiters in antitrust law interpretation-a power which they may jealously guard. However, the trade rule may have some effect because of the peculiar headaches raised by Robinson-Patman: problems are sufficiently difficult and so confused that a court may welcome practical, well-considered interpretations of the Act and apply them as its own.

The possibility that courts may give little or no weight to RobinsonPatman interpretative rules theoretically weakens the Conference Program in this area. Presumably, since reliance on the rules will not insulate parties from attack of private litigants or the Justice Department, willingness to adopt pricing and promotional methods in reliance on the FTC's interpretations may be considerably lessened. However, as a practical matter, this may not occur: the Justice Department has generally left the Robinson-Patman field to the FTC alone, ${ }^{231}$ and private litigants are reluctant to sue unless prior

227. Federal Trade Commission v. Standard Education Soc., 86 F. $2 \mathrm{~d} 692,690$ (2d Cir. 1936), rev'd, 302 U.S. 112, 116 (1937); Heller \& Son v. Federal Trade Commission, 191 F.2d 954 (7th Cir. 1951). For full discussion, see 1 Calrasuss 340-7.

22S. Comment, Antitrust Enforconent by Prizate Parties: Analysis of Dredopnents in the Treble Dannage Srit, 61 Yale L.J. 1011, 1029-33 (1952).

229. E.g., Fashion Originators' Guild v. Federal Trade Commission, 312 C'.S. 457 (1941) (purpose of combating acknowledged tort of "style piracy" does not justify cumbination to boycott tortfeasor copyists). And see sources cited in Comment, surra note 228.

230. Industry sources.

231. Note, Chain Stores Under the Sherman Act, 47 Cos L. Rav. 726,795 (1047). 
Government actions against prospective defendants have paved the way.202 To make sure that a firm will not risk prosecution for action in reliance on the Commission's rules, Commissioner Mason has suggested an immunity statute, ${ }^{233}$ replete with elaborate provisions by which such immunity could be withdrawn by either FTC or Justice Department action if the need arises, ${ }^{\mathbf{2 3 4}}$ Passage of such a statute, perhaps with slight modifications, ${ }^{235}$ should facilitate drafting of Robinson-Patman rules for individual industries to promote, so far as possible under the Act, competitive conditions consistent with a coherent antitrust program.

\section{Impact}

The use of trade practice rules in court proceedings may result in considerable modification of business attitudes toward projected conferences for their industry. ${ }^{236}$ As a result of Lanham Act proceedings, those agreeing to "custom-made" rules in the past because they believed that FTC enforcement would be ineffective must now consider the threat of private litigation based on specific rule determinations. Firms whose skepticism toward rule making

232. Comment, 61 Yale L.J. 1011, 1060 (1952).

233. Mason Proposes Industry Assume Liability for Trade Practice; Madd Bill Drazin Up, Oil Paint \& Drug Rep., Oct. 20, 1947, p. 3. Apparently no effort has as yet been made to secure congressional enactment of the bill. INTERviEws.

234. Under the proposed statute, conferences could be recommended by either the Secretary of Commerce or the Commission, with notice being given to the Attorncy General, who could cancel the proposed conference by certifying it was not in the public interest $(\S 2)$. If there is no adverse report from the Attorney General, the FTC would investigate the industry ( $(3)$. If the Attorney General objects to a rule, and the FTC does not withdraw it, he may institute proceedings in equity to enjoin acts done in compliance with such rule 90 days after objection was filed with the FTC. The FTC will conform rules to the final decision in such litigation (\$ 5). Except for the above, no action, civil or criminal, Governmental or private, under the federal antitrust laws shall be maintained for any act or omission to act resulting from conformity by any signtattory thereto with any rule $(\S 7)$. Draft of Legislation Proposed by Commissioner Mason, 1947, copy in Yale Law Library.

235. It would perhaps be more appropriate if the FTC were required to suspend any rule during Justice Department litigation on legality of conduct in compliance with it. Sheltering firms under an FTC interpretation pending a fittal decision by the courts (id. $\S 5$ ) seems to give too much discretion to the FTC to decide what practices are to be permitted and encouraged in contradiction to Justice Department views on the requirements of the antitrust laws.

236. Widespread requests from industries for conferences indicate a generally favorable attitude toward the current conference program among many groups not presently covered by rules. See note 199 supra. However, there is considerable sentiment against conferences for a variety of reasons: e.g., undesirability of any "unnecessary" Government involvement in control of competitive conditions; fear that FTC investigations in connection with rule formulation will lead to the industry being "harassed" with prosccttions; a belief that the program is mere "empire building" by the FTC; and a general distrust and dislike of any contact with Government lawyers not necessitated by severe problems of unfair practices with the industry. 1952 InduSTRY SURVEY of Rutess. 
derived from a low opinion of the Commission's effectiveness might now give the rule program increased support. More careful scrutiny of the content of proposed rules can be expected at the very least. Other effects on the conference program are problematical.

\section{CONCLUSION}

The scope of deceptive practice, unfair competition, and antitrust regulation is so vast that any agency-let alone an understaffed one-faces an almost impossible task of administration. ${ }^{23 i}$ Enforcement against individual offenders must, because of the size of the job, depend primarily on effectuating industry-wide compliance either through the deterrent effect of selective enforcement or the good faith of industry members in obeying federal laws. But in highly competitive areas, as long as some can effectively evade prosecution or postpone enforcement orders, business pressures operate in devastating fashion to tax good faith heavily and weaken whatever deterrent is created by spasmodic prosecution of selected industry members. Difficulty is compounded since individual enforcement must operate in a highly fluid business world displaying rapid changes of practice. When the members of a particular industry are continually confronted with competitors' questionable but not clearly illegal practices, good faith and fear of prosecution may disappear entirely as motives to refrain from similar practices. Experience indicates all too well that even a much enlarged FTC staff with individual iniormal enfurcement procedures cannot effectively regulate in many of these problem areas.

The FTC's Trade Conference Program proceeds upon a psychological basis entirely different from individual enforcement. In une sense, the Cummission creates the situation where an industry can police itself, both in puilicizing

237. See notes 7, 8, and 10 supra. A recent study reported: "FTC, in sivirt, vas to be at once impartial judge, mentor, fount of knowledge, and defender of the faith. . . . This is a job for a Commission of gods, and anything less may be readily y ardonsed for not achieving perfection." Zealous Hon of FTC, Fortune, Feb. 1952, pp. 107-s. Even where rules have been promulgated, rule administration is a iantastic task for an 11-man unit. E.g.: "The Commission has 179 sets of industry rules under administration comprising 2,393 Group I and Group II rules, involving 954,393 individual members, with a total annual dollar volume of business of over \$̧75 billion." FTC Axs. REp. 64 (1952). FTC receives aid in the control of deceptive advertising from privately organized batt.r business bureaus, which, although without the legal authority of the FTC, ean act with extreme dispatch and achieve considerable results without direct appeal to law. SHArs \& Fox, Business Etrics 257-61 (1937); Churchill, Eyc for Busincss, N.Y. Times Mag., Nov. 18, 1951, pp. 31-2; Hartwell, Sucker's Best Irricud, Collier's, Oct. 30, 1943, p. 44. State legislation aimed at control of deceptive advertising has proved largely ineffectual, except in outlawing the most blatant ialsehoods. 1 Cull:In: 24t. Restricted regulatory or administrative authority over certain kinds of advertising fraud or misrepresentation is scattered among several federal departments and agenciesUnit, Post Office Department, and United States Public Health Service For discussion

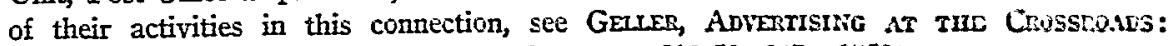
Frdezal Regulation vs. Voluntary Controls 213-52, 267 (1952). 
what practices are currently in vogue to enable formulation of relevant trade rules, and in guarding against subsequent violations of the rules. Of course, lurking in the background is the threat of FTC sanctions, an essential backstop for a successful trade rule program. ${ }^{238}$ But while these may be necessary to insure that preventative action will be taken against offenders, and thus that good faith adherents to the rules will not suffer competitively, the Conference Program ultimately depends upon industry cooperation. Patently, since problems may be industry-wide and consequently unmanageable by even an enlarged enforcement agency, reliance upon industry cooperation and self policing is a sensible device.

Danger is involved, however, in the process of drafting "custom-made" rules. To facilitate efforts to secure voluntary compliance with the rules, the FTC apparently goes to great lengths to draft rules which will be generally acceptable to the industry. ${ }^{230}$ This could lead the Commission into a willingness to give unreserved aid to participating firms alarmed over "deceptive," "unfair," or "cut throat" practices of others. Yet prohibitions of many of the practices which are so termed may be unnecessary limitations on the range of competitive methods. ${ }^{240}$ At the same time, should the FTC provide, as it did in the past, a quasi-official sanction for agreements violating the antitrust laws, industry-wide conferences would definitively defeat their very purposes. Currently, the considerable care with which the Commission formulates the rules indicates that its staff is well aware of these problems, and no present abuses are readily discernible. ${ }^{241}$ The future might witness opposite results.

238. Since a significant portion of firms complying with FTC trade rules after their promulgation do so because of fear of FTC prosecution or a desire to avoid any lesser entanglements with the Commission, 1953 Journal Surver, a strong enforcement arm seems essential to the success of the conference program. See FTC TRANSCRIPT, HEANings on Third Defictency Appropriation Bill for 1946, p. 9 (June 7, 1946), copy in Yale Law Library.

239. There appear to be virtually no complaints from industry that the FTC custommade rules are unacceptable to the industry. 1952 INDUSTRY SURveY of RuLES. But cf. recent turmoil over rules in New England heating oil industry, note 172 supra.

240. A possible example of such industry views as to "unfair trade practices" are the "Ten Commandments" for oil jobbers distributed by the Iowa Independent Oil Jobbers Ass'n which include:

"1. It is unfair to invade a competitor's territory when you are selling at a lower price in your bulk plant area than your competitor who is operating in the adjacent territory when he might have a normal price.

"2. It is an unfair trade practice to loan pumps or tanks to the consuming public, which in turn forces the competitor to do likewise and in the end you both indulged in unprofitable merchandising. ...

". . .

"7. It is unfair for any supplier or jobber to offer long term credit to a compctitor's customer in order to get the account. ...."

National Petroleum News, Dec. 28, 1949, p. 35.

241. See, e.g., views of the FTC's chief economist and Director of its Bureau of Industry Economics, Edwards, Maintalning Conpetition 2 (1952); Zealous Men of FTC, 
But to some extent, this danger is minimized by the fact that other enforcers such as the Food and Drug Administration, the Justice Department, and private parties, constitute checks on FTC rule-making.

As it is now operating, the Trade Conference Program gives considerable promise for effective enforcement of many FTC functions. Of course, the program is not a panacea. It probably will not be effective in certain areas, such as those involving direct door to door selling where business firms purportedly exercise little control over the antics of thieir salesmen.? Moreover, should FTC spread itself too thin with too many conferences, should rules not be kept up to date, or should careful checks on rule compliance te waived, the Conference Program will become nothing but a ritual. Perhaps, in many areas of the economy, this is the program's current effect beeause of the undermanned FTC forces: an eleven-man Rules Administration Unit is somewhat farcical. If the Commission staff is increased and operates the Conference Program within limitations geared to its size, there is every reason to anticipate fruitful results.

Fortune, Feb., 1952, pp. 106, 132. In fact, implied criticism was vuiced against the Commission's complete control over rule formulation at the present time by Weil, FTC's Trade Practice Rules: How Do They Affoct You?, Frinter's Ink, Sept. 2, 194y, 1p. 42, 4\%. In contrast, during the period of rule abuse in the late $1920 \mathrm{~s}$, FTC permitted industry to control rule content. In fact, a loud outery was raised in 1029 when the Commision dropped a provision submitted by an industry and substituted a new one of its $0 \mathrm{an}$ devising. GASKILI 119.

242. See note 198 supra. 